Article

\title{
Empirical Characterization Factors for Life Cycle Assessment of the Impacts of Reservoir Occupation on Macroinvertebrate Richness across the United States
}

\author{
Gabrielle Trottier $^{1, *(\mathbb{D})}$, Katrine Turgeon ${ }^{2} \mathbb{D}$, Francesca Verones ${ }^{3}$, Daniel Boisclair ${ }^{4}$, Cécile Bulle ${ }^{1,5}$ \\ and Manuele Margni 1,6
}

1 CIRAIG, Département de Mathématiques et Génie Industriel, Polytechnique Montréal, Montréal, QC H3C 3A7, Canada; bulle.cecile@uqam.ca (C.B.); manuele.margni@polymtl.ca (M.M.)

2 ISFORT, Université du Québec en Outaouais, Ripon, QC J0V 1V0, Canada; katrine.turgeon@uqo.ca

3 Industrial Ecology Program, Department of Energy and Process Engineering, NTNU, 7491 Trondheim, Norway; francesca.verones@ntnu.no

4 Département des Sciences Biologiques, Université de Montréal, Montréal, QC H3C 3A7, Canada; daniel.boisclair@umontreal.ca

5 Département de Stratégie, Responsabilité Sociale et Environnementale, École des Sciences de la Gestion, Université du Québec à Montréal, Montréal, QC H3C 3P8, Canada

6 Institute of Sustainable Energy, HES-SO Valais, 1950 Sion, Switzerland

* Correspondence: gabrielle.trottier@polymtl.ca; Tel.: +514-340-4711

Citation: Trottier, G.; Turgeon, K.; Verones, F.; Boisclair, D.; Bulle, C.; Margni, M. Empirical Characterization Factors for Life Cycle Assessment of the Impacts of Reservoir Occupation on Macroinvertebrate Richness across the United States. Sustainability 2021, 13, 2701. https://doi.org/10.3390/ su13052701

Received: 4 February 2021

Accepted: 1 March 2021

Published: 3 March 2021

Publisher's Note: MDPI stays neutral with regard to jurisdictional claims in published maps and institutional affiliations.

Copyright: (c) 2021 by the authors. Licensee MDPI, Basel, Switzerland. This article is an open access article distributed under the terms and conditions of the Creative Commons Attribution (CC BY) license (https:// creativecommons.org/licenses/by/ $4.0 /)$.

\begin{abstract}
The transformation of a river into a reservoir and the subsequent occupation of the riverbed by a reservoir can impact freshwater ecosystems and their biodiversity. We used the National Lake Assessment (134 reservoirs) and the National Rivers and Streams Assessment (2062 rivers and streams) of the United States Environmental Protection Agency in order to develop empirical characterization factors (CFs; in Potentially Disappeared Fraction of species [PDF]) evaluating the impacts of reservoir occupation on macroinvertebrate richness (number of taxa) at the reservoir, ecoregion and country spatial scales, using a space-for-time substitution. We used analyses of variance, variation partitioning, and multiple regression analysis to explain the role of ecoregion (or regionalization; accounting for spatial variability) and other potentially influential variables (physical, chemical and human), on PDFs. At the United States scale, 28\% of macroinvertebrate taxa disappeared during reservoir occupation and PDFs followed a longitudinal gradient across ecoregions, where PDFs were higher in the west. We also observed that high elevation, oligotrophic and large reservoirs had high PDF. This study provides the first empirical macroinvertebrate-based PDFs for reservoir occupation to be used as CFs by LCA practitioners. The results provide strong support for regionalization and a simple empirical model for LCA modelers.
\end{abstract}

Keywords: Life Cycle Assessment; reservoirs; biodiversity; macroinvertebrates; water management; aquatic ecology

\section{Introduction}

Water abstraction (withdrawal), regulation of water flow by dams (storage reservoirs for drinking water, flood control, and energy production), and water diversion by channels (irrigation and navigation) have benefited human populations worldwide [1-3]. However, despite clear societal benefits, the use of water is often accompanied by a myriad of environmental impacts [4-8].

The environmental impacts brought about by dams are well documented [9]. Geomorphology, water depth and hydrological regime are notably altered. Changes in water depth, temperature and total dissolved solids affect ecosystem productivity [10-13]. A change in the hydrological regime (lotic into a lentic ecosystem, upstream of the dam) affects several physical and biological processes, as well as organisms' capacities to thrive and 
survive in these ecosystems. These changes can ultimately impact ecosystem biodiversity, productivity and the provision of ecosystem services [14-16]. To sustain these services and preserve the ecological integrity of our freshwater ecosystems, we must understand the impacts of dams and reservoirs on freshwater biodiversity. In this article, we are interested in macroinvertebrate richness (number of taxa).

Few studies have investigated the impacts of dams and reservoirs on macroinvertebrate taxa richness. Flow regulation and water level fluctuations (also known as drawdown) [17-22] can negatively impact macroinvertebrate richness [23-26]. However, Glowacki et al. [27] and Floss et al. [28] observed higher taxa richness downstream of a dam, or in regulated rivers, as opposed to natural ones [29]. Marchetti et al. [30] found little difference between richness in reduced flows versus higher "natural-like" flows. The literature highlights divergent macroinvertebrate responses to altered flows.

While the impact of dams and reservoirs on macroinvertebrate richness is an interesting subject on its own, in this article, we are interested in integrating these impacts into an engineering tool that helps decision making (Life Cycle Assessment; LCA). This work specifically aims to assess the potential loss of macroinvertebrates due to dams and reservoirs for multiple usages (hydropower, flood control, irrigation, drinking water, transportation or recreation). For example, in the case of hydropower, we would quantify how many macroinvertebrates would potentially be lost following the implementation of a dam and the creation of a reservoir (transformation from a river into a reservoir and the occupation of the former riverbed by a reservoir) compared to a natural reference and use this information to relate this loss to the kilowatt-hour produced.

LCA is an interdisciplinary and internationally used approach that evaluates the potential environmental impacts of a product, process or service throughout its entire life cycle from resource extraction to end of life [31]. LCA is often used to support the selection of environmentally preferable alternatives for eco-design purposes and to identify the largest potential environmental impacts and trade-offs in a product's life cycle [32]. Emissions, resource extraction and change in land use (inventory flows) related to all activities involved in the life cycle of a product, process or service are first inventoried, and this is called the Life Cycle Inventory (LCI). Then, these inventory flows are translated into potential environmental impacts through characterization factors (CFs) [33]. In other words, CFs are used to translate inventory flows into impact indicators. Impact indicators are then attributed to Areas of Protection (AoP), which traditionally include ecosystem quality, human health, and resources and ecosystem services [34]. Life Cycle Impact Assessment (LCIA) is the characterization and attribution of the impact. For the ecosystem quality AoP, the use of Potentially Disappeared Fraction of species (PDF), which can also account for time and space, is recommended as a robust impact indicator [34].

The impacts of the transformation of a river into a reservoir (and its subsequent occupation by the reservoir, for a given amount of time) on ecosystem quality have received little attention in LCA. To our knowledge, only a few attempts have been made to evaluate changes in fish richness in relation to hydropower within a LCA framework (see Turgeon et al. [35] and Dorber et al. [36]). Moreover, this type of work has only been conducted on fish [35] and/or mostly relies on theoretical species richness curves, such as the Species-Discharge Relationship (SDR) [36] or the Species-Area Relationship (SAR). Because these curves are based on ecosystems that are in a state of equilibrium, they are not especially representative of the biological reality in a dam/reservoir impacted environment $[4,37]$.

In this study, the objective is to assess the potential impacts of reservoir occupation (transforming a river into a reservoir and the subsequent occupation of the riverbed by the reservoir), upstream of the dam, on changes in macroinvertebrate richness using biological empirical data rather than theoretical curves. We used a dataset of 134 reservoirs (impacted sites) and 2062 rivers and streams (reference sites) across the United States and used a space-for-time substitution approach (reference versus impacted sites instead of Before-After assessment; [38]). We used PDF as a response variable, derived from reference and impacted macroinvertebrate richness, at three spatial scales: the scale of the 
United States, the scale of nine ecoregions, and the scale of singular reservoirs. We then used variation partitioning to examine which explanatory variables, from a set of 37 , best explained the observed variation in reservoir PDFs. Finally, we developed an empirical explanatory model to be used by LCA modelers and practitioners, using reservoir-related explanatory variables to explain variation in PDFs. The originality of this study relies (1) on the choice of a new group of aquatic organisms (macroinvertebrates), which should be monitored together with other types of organisms (fish, aquatic vegetation), within a holistic perspective; and (2) the use of empirical values of richness instead of model predictions from theoretical curves to develop empirical PDFs for reservoir occupation in LCA studies. This is the first study providing PDFs for the impact of reservoir occupation on macroinvertebrate richness in LCA studies.

\section{Material and Methods}

\subsection{Life Cycle Impact Assessment (LCIA) Framework}

CFs are determined by characterization models based on one of two methods. The first method uses environmental mechanisms of a physical, chemical or biological nature, and links inventory flows (emissions of pollutant, the extraction/consumption of a resource or a change of land use) to impact indicators. The USEtox model [39], for example, builds mechanistic cause-effect chains to account for the environmental fate, exposure, and effects to potential ecotoxicity impacts from toxic emissions. Alternatively, the second method uses empirical observations of the state of the environment, assuming a causality between the observed impact and the inventory flows. For instance, de Baan et al. [40] calculated CFs for several types of land use relying on empirical species richness data from both human-modified and undisturbed land in the same region.

Two categories of impact indicators exist for the ecosystem quality AoP. The first quantifies the temporary loss of species in time and space, and is expressed in PDF. $\mathrm{m}^{2} \cdot \mathrm{yr}$ (Potentially Disappeared Fraction of species over a given area and duration) [41] or in species.yr [42]. The second quantifies the permanent loss of species at the continental or global scale and is expressed in PDF [40,43]. Both categories of indicators are relevant and complementary to one another. The first allows the assessment of temporary degradation of an ecosystem that will ultimately recover, whereas the second allows the assessment of the absolute loss of species. In this study, we chose to use the first category of indicators (temporary loss of species in time and space) to quantify the temporary damage on freshwater ecosystems due to reservoir occupation in space and time, using macroinvertebrate richness.

The framework used in de Baan [40] and Chaudhary [43] for change in land occupation has been adapted to assess the occupation of a water body (with an inventory flow expressed in surface-time units; $\mathrm{m}^{2} \cdot \mathrm{yr}$ ). In de Baan [40] and Chaudhary's [43] approaches, the impact indicator is developed from an empirical model assessing land use impacts on biodiversity, and is expressed in PDF. $\mathrm{m}^{2} \cdot \mathrm{yr}$, with a characterization factor expressed in PDF (implicitly PDF. $\mathrm{m}^{2} \cdot \mathrm{yr} / \mathrm{m}^{2} \cdot \mathrm{yr}$ of land occupied). In our study, the CF is also expressed in PDF units, or implicitly PDF $\cdot \mathrm{m}^{2} \cdot \mathrm{yr} / \mathrm{m}^{2} \cdot \mathrm{yr}$ of water body occupied. This CF is the observed change in richness, with respect to a reference macroinvertebrate community, and is multiplied by the inventory flow $\left(\mathrm{m}^{2} \cdot \mathrm{yr}\right.$ of water body occupied during a given time) to obtain an impact score expressed in PDF. $\mathrm{m}^{2} \cdot \mathrm{yr}$. We did not measure the damage due to water body transformation (change of water body area, according to certain requirements of a new occupation process, measured in surface unit; [44,45]) but only the damage of water body occupation, although both impacts are complementary, due to the lack of available post-transformation, water body recovery data.

\subsection{Data Collection}

\subsubsection{Macroinvertebrate Richness}

To extract data on macroinvertebrate richness in reservoirs (impacted sites, after impoundment), we used the 2012 National Lake Assessment (NLA), a United States Envi- 
ronmental Protection Agency (USEPA) effort that surveys ponds, lakes and reservoirs in the United States, as well as their associated biological, chemical, physical and recreational characteristics [46]. From this dataset, we retrieved macroinvertebrate richness (RICHNESS; taxonomic resolution at the genus level, except for oligochaetes, mites, and polychaetes, which were identified to the family level, and ceratopogonids at the subfamily level; [47]), a unique identifier (UID) for each reservoir, latitude (LAT), longitude (LON), ecoregion (ECO), and a suite of environmental variables from 134 reservoirs across the United States (Figure 1; reservoirs shown in black; Table 1).

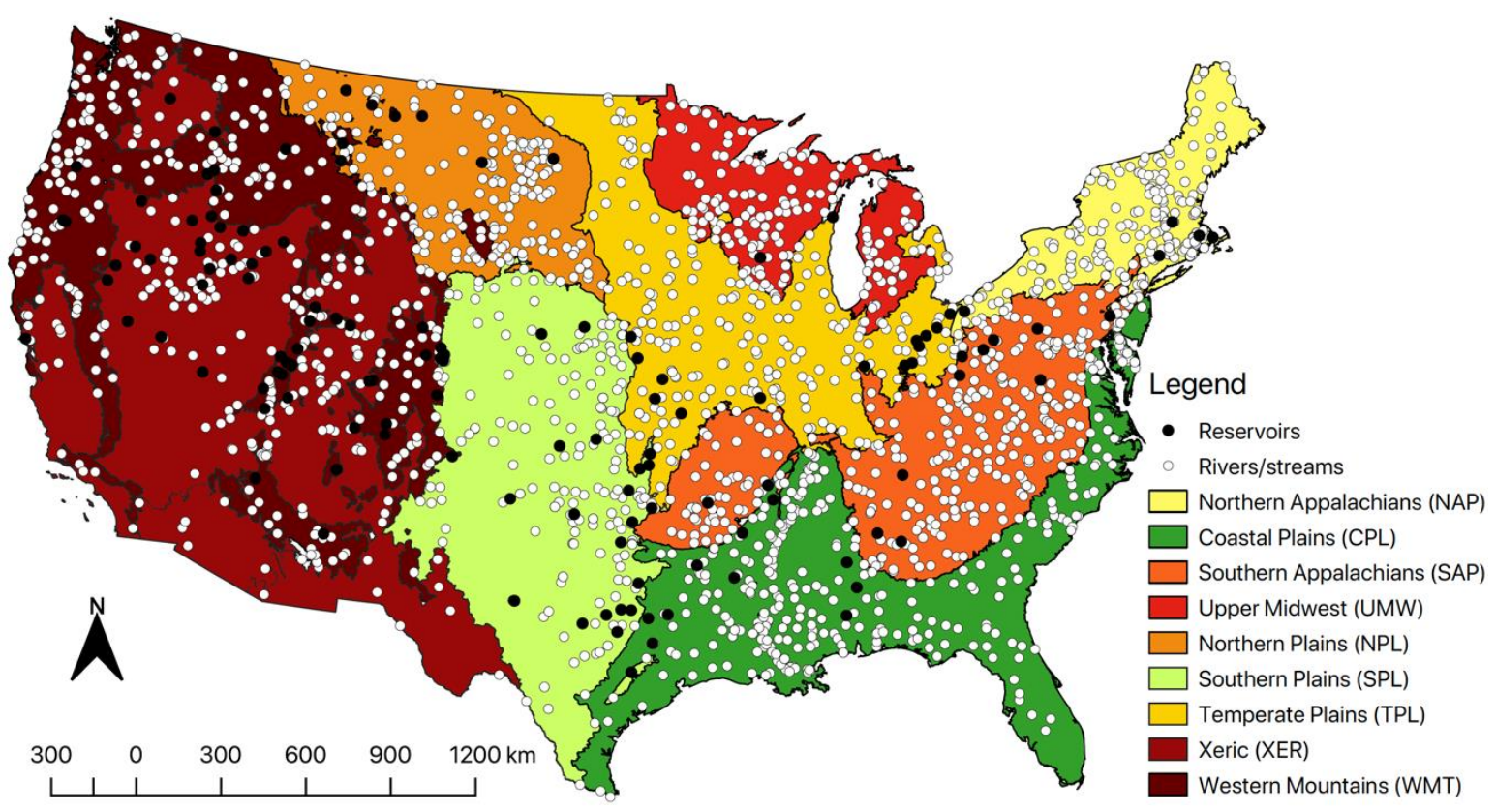

Figure 1. Map of the distribution of National Lake Assessment (NLA) reservoirs ( $n=134$; black circles) and National River and Streams Assessment (NRSA) rivers and streams ( $n=2062$; white circles) from the United States Environmental Protection Agency (USEPA), as well as the nine color-coded ecoregions.

To extract data on macroinvertebrate richness in rivers and streams (reference sites, before impoundment), we used the 2008-2009 National Rivers and Streams Assessment (NRSA), a USEPA initiative to survey United States rivers and streams' biological, chemical, physical, and recreational characteristics [48]. The same variables were collected (UID, LAT, LON, ECO and RICHNESS) for 2062 rivers and streams across the United States (Figure 1; rivers and streams shown in white). Environmental variables found in NLA reservoirs were not available for rivers (no elevation, no surface area and no trophic state, for example). Rivers and streams are referred to as natural reference sites and are not considered as unpolluted or pristine. They represent a wide range of conditions (probability-based design) of rivers that could have been transformed and occupied by reservoirs.

As no macroinvertebrate richness information was available for reservoirs preimpoundment conditions, we applied a space-for-time substitution approach [38], that is substituting spatial data for unavailable temporal data, assuming that the temporal relationship can be substituted by the spatial relationship between an explanatory variable and a response variable [49]. We assumed that macroinvertebrate richness in rivers and streams in the surrounding area of a reservoir from the NLA dataset would be comparable to what would have been found in a river prior to its transformation and occupation by a reservoir and thus, could be used to derive PDFs. Both the USEPA-NLA and NRSA surveys used the same sampling procedure. Macroinvertebrates were collected using a semi-quantitative sampling of multiple habitats (in reservoirs or in rivers and streams) with a $500 \mu \mathrm{m}$ mesh D-frame dip net (see USEPA [50] and USEPA [51] for more information). 
Table 1. Table showing the explanatory variables from four matrices using the United State Environmental Protection Agency-National Lake Assessment (USEPA-NLA) dataset. The table shows the explanatory variables, a short definition of the variables, their respective units and the type of variable ( $\mathrm{N}$ for numerical and $\mathrm{F}$ for categorical). Variables in bold are the most influential variables to explain variation in Potentially Disappeared Fraction of species (PDF) following variation partitioning.

\begin{tabular}{|c|c|c|c|c|}
\hline Matrix & Variable & Definition & Units & Type \\
\hline \multirow[t]{11}{*}{ Spatial } & Latitude & Latitude of reservoir & Decimal degrees & $\mathrm{N}$ \\
\hline & Longitude & Longitude of reservoir & Decimal degrees & $\mathrm{N}$ \\
\hline & Ecoregion & $\begin{array}{l}\text { National Aquatic Resource Surveys (NARS) 9-level reporting } \\
\text { regions, based on aggregated Omernik [52] level III ecoregions }\end{array}$ & 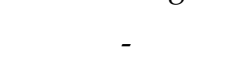 & $\mathrm{F}$ \\
\hline & Temperature & Annual mean air temperature, specific to ecoregion & ${ }^{\circ} \mathrm{C}$ & $\mathrm{N}$ \\
\hline & Precipitation & Annual mean precipitations, specific to ecoregion & $\mathrm{mm}$ & $\mathrm{N}$ \\
\hline & Forested & Percentage of land cover in ecoregion that is forested & $\%$ & $\mathrm{~N}$ \\
\hline & Cultivated pasture & Percentage of land cover in ecoregion that is cultivated pastures & $\%$ & $\mathrm{~N}$ \\
\hline & Wetlands & Percentage of land cover in ecoregion that is wetlands & $\%$ & $\mathrm{~N}$ \\
\hline & Grassland and shrubs & $\begin{array}{c}\text { Percentage of land cover in ecoregion that is grasslands } \\
\text { and shrubs }\end{array}$ & $\%$ & $\mathrm{~N}$ \\
\hline & Developed & Percentage of land cover in ecoregion that is developed & $\%$ & $\mathrm{~N}$ \\
\hline & Water or barren & Percentage of land cover in ecoregion that is water or barren & $\%$ & $\mathrm{~N}$ \\
\hline \multirow[t]{5}{*}{ Physical } & Area & Surface area of reservoir & ha & $\mathrm{N}$ \\
\hline & Elevation & Elevation reservoir coordinates & $\mathrm{m}$ & $\mathrm{N}$ \\
\hline & Macrophytes & Index of total cover of aquatic macrophytes of reservoir & - & $\mathrm{N}$ \\
\hline & Shallow water & Shallow water habitat condition indicator & - & $\mathrm{N}$ \\
\hline & Riparian vegetation & Riparian vegetation condition indicator & - & $\mathrm{N}$ \\
\hline \multirow[t]{10}{*}{ Chemical } & Trophic state & Trophic state of reservoir (oligotrophic and eutrophic) & - & $\mathrm{F}$ \\
\hline & Secchi & Secchi depth & $\mathrm{m}$ & $\mathrm{N}$ \\
\hline & DOC & Dissolved Organic Carbon level & $\mathrm{mg} / \mathrm{L}$ & $\mathrm{N}$ \\
\hline & PTL & Total Phosphorus Level & $\mu \mathrm{g} / \mathrm{L}$ & $\mathrm{N}$ \\
\hline & Color & Water color & PCU & $\mathrm{N}$ \\
\hline & Conductivity & Water conductivity level & $\mu \mathrm{s} / \mathrm{cm}$ & $\mathrm{N}$ \\
\hline & NTL & Total Nitrogen Level & $\mathrm{mg} / \mathrm{L}$ & $\mathrm{N}$ \\
\hline & $\mathrm{pH}$ & $\mathrm{pH}$ level & $\mathrm{pH}$ scale & $\mathrm{N}$ \\
\hline & Methylmercury & Top sediment methylmercury level & $\mathrm{ng} / \mathrm{L}$ & $\mathrm{N}$ \\
\hline & Chl- $\alpha$ & Chlorophyll- $\alpha$ measurement result of reservoir & $\mu \mathrm{g} / \mathrm{L}$ & $\mathrm{N}$ \\
\hline \multirow[t]{12}{*}{ Human } & Buildings & Human influence by buildings around reservoir shoreline & - & $\mathrm{N}$ \\
\hline & Commercial & $\begin{array}{c}\text { Human influence by commercial activities around } \\
\text { reservoir shoreline }\end{array}$ & - & $\mathrm{N}$ \\
\hline & Crops & Human influence by crops around reservoir shoreline & - & $\mathrm{N}$ \\
\hline & Docks & Human influence by docks around reservoir shoreline & - & $\mathrm{N}$ \\
\hline & Landfill & Human Influence by landfill around reservoir shoreline & - & $\mathrm{N}$ \\
\hline & Lawn & Human influence by lawn around reservoir shoreline & - & $\mathrm{N}$ \\
\hline & Park & Human influence by parks around reservoir shoreline & - & $\mathrm{N}$ \\
\hline & Pasture & Human influence by pastures around reservoir shoreline & - & $\mathrm{N}$ \\
\hline & Powerlines & Human influence by powerlines around reservoir shoreline & - & $\mathrm{N}$ \\
\hline & Roads & Human influence by roads around reservoir shoreline & - & $\mathrm{N}$ \\
\hline & Walls & Human influence by walls around reservoir shoreline & - & $\mathrm{N}$ \\
\hline & Other & Human influence by other around reservoir shoreline & - & $\mathrm{N}$ \\
\hline
\end{tabular}

\subsubsection{Ecoregions}

Reservoirs and rivers were distributed across nine terrestrial ecoregions, a priori defined by Omernik [52] and Herlihy et al. [53]. Ecoregions are based on similar environmental characteristics (climate, vegetation, soil type and geology) and macroinvertebrate assemblages (Figure 1); Coastal Plains (CPL), Northern Appalachians (NAP), Northern Plains (NPL), Southern Appalachians (SAP), Southern Plains (SPL) Temperate Plains (TPL), Upper Midwest (UMW), Western Mountains (WMT) and Xeric (XER). This aggregation of ecoregion was adopted for both the NLA and NRSA surveys [54]. For each ecoregion, 
we also extracted land cover variables [54] (Table 1; spatial matrix) and variables related to human impacts (Table 1; human matrix).

\subsubsection{Native Riverine Taxa Definition}

The taxa pool observed in rivers and streams was used as a baseline to compare taxa richness before and after reservoir occupation (reference; native riverine taxa). We used only native riverine taxa and excluded all new taxa that would be encountered in a lakelike habitat (reservoir), since they would most likely not be present in a pre-reservoir occupation, river-like habitat. We considered using pairwise comparisons (impacted site paired with a single reference site) or reference sites found within a fixed radius or within the ecoregion. We decided to go with an ecoregion mean reference because there is neither literature to support the choice of a singular river when multiple rivers were surrounding a reservoir nor to support a fixed radius distance $(25 \mathrm{~km}, 50 \mathrm{~km})$. Comparing to a mean reference in each ecoregion, instead of a single river or stream close to the reservoir, ensures that we are measuring the impacts from a set of reference conditions and not a singular pristine, or impacted, river or stream. Moreover, as specified in Section 2.2.2, ecoregions were defined based on similar macroinvertebrate assemblages, which further reinforce the choice of this scale, at the ecological point of view, for our study.

\subsubsection{PDFs Calculation}

We calculated PDFs as the difference in richness between river $(x)$ and reservoir richness $(y)$, divided by the river richness $(x)$. The PDF is a dimensionless proportion ranging between -1 and 1 . At the United States scale ( PDF $\left._{\text {usa }}\right)$, we compared the overall United States mean native riverine richness in rivers and streams (one observation of richness per river or stream averaged over the United States; $\bar{x}_{u s a} ; n=2062$ ) to the overall United States mean richness in reservoirs (one observation of richness per reservoir averaged over the United States; $\bar{y}_{u s a} ; n=134$ ) to obtain a United States-specific change in richness, as per Equation (1);

$$
\mathrm{PDF}_{\mathrm{usa}}=\frac{\bar{x}_{u s a}-\bar{y}_{u s a}}{\bar{x}_{u s a}}
$$

At the ecoregion scale $\left(\mathrm{PDF}_{\mathrm{eco}}\right)$, we compared ecoregion mean native riverine richness of all rivers and streams (one observation of richness per river or stream averaged over each ecoregion; $\bar{x}_{\text {eco }}$ ) to the ecoregion mean richness in reservoirs (one observation of richness per reservoir averaged over each ecoregion; $\bar{y}_{\text {eco }}$ ) to obtain an ecoregion-specific change in richness, as per Equation (2);

$$
\mathrm{PDF}_{\mathrm{eco}}=\frac{\bar{x}_{e c o}-\bar{y}_{e c o}}{\bar{x}_{e c o}}
$$

At the reservoir scale $\left(\mathrm{PDF}_{\mathrm{res}}\right)$, we compared ecoregion mean native riverine richness of all rivers and streams (one observation of richness per river or stream averaged over each ecoregion; $\bar{x}_{\text {eco }}$ ) to the richness of a specific reservoir within the same ecoregion (one specific richness observation per reservoir, no averaging; $\left.y_{\text {res }}\right)$ to obtain a reservoir-specific change in richness, as per Equation (3);

$$
\mathrm{PDF}_{\mathrm{res}}=\frac{\bar{x}_{e c o}-y_{\text {res }}}{\bar{x}_{\text {eco }}}
$$

\subsection{Data Analysis and Empirical Modelling \\ 2.3.1. Regionalization and ANOVA}

Regionalization is a critical aspect in LCA $[55,56]$. It accounts for existing spatial variability to improve results' representativeness and reduce spatial uncertainties [55]. CFs must be developed at an appropriate scale to capture the environmental impacts of a product, process or service, and inform decision makers. As a first step, we ran a one-way randomized-group analysis of variance (ANOVA) to determine whether $\mathrm{PDF}_{\text {eco }}$ differed across ecoregions (ecoregion scale) and thus test the relevance of this regionalization scale. 
We assessed the significance of regionalization at the ecoregion scale and identified which ecoregions were significantly different from each other based on the standardized mean difference and its confidence interval (CI). All statistical analyses were made using $\mathrm{R}$ version 3.0.2 [57]. We conducted the ANOVA with the ind.oneway.second function in the rpsychi R package version 0.8 [58].

\subsubsection{Variation Partitioning to Explain the Variation Observed in Our $\mathrm{PDF}_{\text {res }}$}

As a second step, we were interested in understanding which variables explained the variation observed in $\mathrm{PDF}_{\text {res }}$ at the reservoir scale in the United States. To do so, we used variation partitioning [59], a statistical analysis that describes how a set of explanatory matrices explains the shared variation observed in a response variable (PDF). We built four explanatory matrices (spatial, physical, chemical and human matrices) based on the available descriptive variables from the NLA and NRSA datasets and selected a set of variables potentially influencing macroinvertebrate richness based on expert judgment. The spatial matrix included variables describing the location of the reservoirs; latitude, longitude, ecoregion, temperature, precipitation and types of land covers (forested, cultivated pastures, wetlands, grasslands and shrubs, developed and water or barren). The physical matrix included variables describing the reservoir; reservoir area, elevation, shallow water and riparian vegetation. The chemical matrix included variables that describe the biochemical state of the reservoir; trophic state, Secchi depth, dissolved organic carbon (DOC), total phosphorus level (TPL), water color, conductivity, total nitrogen level (TNL), $\mathrm{pH}$, methylmercury and chlorophyll- $\alpha(\mathrm{Chl}-\alpha)$. The human matrix included variables describing the human activity, impact or influence around the reservoir shoreline; influence of buildings, commercial activities, crops, docks, landfills, lawns, parks, pastures, powerlines, roads, walls and others. See Table 1 for a complete description of the variables included in each matrix. To achieve the most parsimonious analysis, we performed a stepwise selection procedure on each explanatory matrix to identify which variable, or combination of variables, best-explained the variation in $\mathrm{PDF}_{\text {res }}$ (variables in bold; Table 1). Variable selection was performed with the function ordiR2step and variation partitioning was conducted with the varpart function in the vegan $R$ package version 2.5-2 [60].

\subsubsection{Empirical Modelling}

As a third step, we used a multiple linear regression ( $\mathrm{lm}$ function in the stat $\mathrm{R}$ package version 3.4.2; [57]) to develop an empirical model to be used by LCA modellers and practitioners. This empirical model can be used to assess $\mathrm{PDF}_{\text {res }}$ from known values of explanatory variables (related to the reservoir, not the rivers and streams) when we do not have information about empirical change in macroinvertebrate richness in impacted and/or reference sites, within a specific frame of application and range of environmental variables (also called interpolation). We used the variables identified by the variation partitioning analysis as the most influential variables to explain the variation in $\mathrm{PDF}_{\text {res }}$. We checked whether assumptions associated with multiple linear regression were violated (the residuals are independent, normal, have a mean of 0 and are homoscedastic; Figures A1 and A2), we deleted a few outliers, and performed a model selection procedure. We applied a manual backward selection procedure, used the recommended information theoretic approach based on the Akaike information criterion (AIC; [61]) and the Bayesian information criterion (BIC; [62]) to compare the seven candidate models, and selected the model with the highest support (Table 2). For each explanatory variable selected in the final model, we extracted estimates and standard error (SE), where the estimates represent the direction and magnitude of $\mathrm{PDF}_{\text {res. }}$. 
Table 2. Summary of statistical candidate models (Akaike information criterion; $\triangle \mathrm{AIC}$, and Bayesian information criterion; BIC), where PDF stands for Potentially Disappeared Fraction of species, ELE for elevation, AREA for surface area, T.S. for trophic state, $\mathrm{PH}$ for $\mathrm{pH}$ level, LAWN for influence of lawns and ROAD for influence of roads. For each candidate model, the estimate for the intercept is labelled $b_{\text {int }}$ and all other $b \mathrm{~s}\left(b_{E L E}, b_{A R E A}, b_{T . S .}, b_{P H}, b_{L A W N}\right.$, and $\left.b_{R O A D}\right)$ estimate for the slope of their respective variable. See Table 1 for full description of the variables used. $\S$ Marginally significant.

\begin{tabular}{|c|c|c|c|}
\hline Models & Non-Significant Variables & $\Delta \mathrm{AIC}$ & BIC \\
\hline $\begin{array}{l}\text { (A) PDF } b_{\text {int }}+b_{E L E}{ }^{*} \operatorname{sqrt}(\mathrm{ELE})+b_{A R E A}{ }^{*} \log 10(\mathrm{AREA})+b_{T . S .}{ }^{*} \text { T.S. }+b_{P H}{ }^{*} \mathrm{PH}+ \\
b_{L A W N}{ }^{*} \log 10(\mathrm{LAWN})+b_{R O A D}{ }^{*} \log 10(\mathrm{ROAD})\end{array}$ & $\mathrm{PH} \&, \mathrm{LAWN}$ and ROAD & 2 & 27 \\
\hline $\begin{array}{l}\text { (B) PDF } b_{i n t}+b_{E L E}{ }^{*} \operatorname{sqrt}(\mathrm{ELE})+b_{A R E A}{ }^{*} \log 10(\mathrm{AREA})+b_{T . S .}{ }^{*} \mathrm{~T} . \mathrm{S} .+b_{P H}{ }^{*} \mathrm{PH}+ \\
b_{L A W N}{ }^{*} \log 10(\mathrm{LAWN})\end{array}$ & $\mathrm{PH}^{\S}$ and LAWN & 1 & 24 \\
\hline (C) PDF $b_{\text {int }}+b_{E L E}{ }^{*} \operatorname{sqrt}(\mathrm{ELE})+b_{A R E A}{ }^{*} \log 10(\mathrm{AREA})+b_{\text {T.S. }}{ }^{*}$ T.S. $+b_{P H^{*}}{ }^{*} \mathrm{H}$ & $\mathrm{PH} \S$ & 0 & 20 \\
\hline (D) PDF $\sim b_{i n t}+b_{E L E}{ }^{*} \operatorname{sqrt}(\mathrm{ELE})+b_{A R E A}{ }^{*} \log 10(\mathrm{AREA})+b_{T . S .}{ }^{*} \mathrm{~T} . \mathrm{S}$. & None & 2 & 20 \\
\hline (E) $\mathrm{PDF} \sim b_{\text {int }}+b_{E L E}{ }^{*} \mathrm{sqrt}(\mathrm{ELE})+b_{A R E A}{ }^{*} \log 10(\mathrm{AREA})$ & None & 8 & 23 \\
\hline (F) PDF $\sim b_{i n t}+b_{E L E}{ }^{*} \operatorname{sqrt}(\mathrm{ELE})$ & None & 19 & 32 \\
\hline (G) $\mathrm{PDF} \sim b_{\text {int }}$ & - & 52 & 63 \\
\hline
\end{tabular}

\section{Results}

\section{1. $P D F_{u s a}$ and Variation in $P D F_{\text {eco }}$ across Ecoregions}

A total of 973 native riverine macroinvertebrate taxa were inventoried throughout the United States. The mean native riverine richness per ecoregion varied from $26.1 \pm 13.1$ to $46.0 \pm 13.8$ (mean \pm standard deviation [SD]; Tables 3 and A1). The mean reservoir richness per ecoregion varied from $19.7 \pm 7.9$ to $39.8 \pm 9.4$ (mean \pm SD; Table 3). Our empirically derived $\mathrm{PDF}_{\mathrm{usa}}$ and $\mathrm{PDF}_{\mathrm{eco}}$ showed a loss in macroinvertebrate richness due to reservoir occupation in the United States and this loss followed a longitudinal gradient associated with the ecoregions (Figure 2). At the United States scale, 28\% of macroinvertebrate taxa disappeared in response to river impoundment $\left(\mathrm{PDF}_{\mathrm{usa}}=0.284 \pm 0.168\right.$ [mean \pm SD]; Table 3 and Figure 2). At the ecoregion scale, seven out of nine ecoregions (78\%) showed a statistically significant loss of macroinvertebrate taxa, with $\mathrm{PDF}_{\mathrm{eco}}$ varying from $0.135 \pm 0.052$ to $0.464 \pm 0.235$. Two ecoregions (CPL and SPL), showed a significant increase in macroinvertebrate taxa $\left(\mathrm{PDF}_{\mathrm{CPL}}=-0.158 \pm 0.100\right.$ and $\mathrm{PDF}_{\mathrm{SPL}}=-0.021 \pm 0.014$;

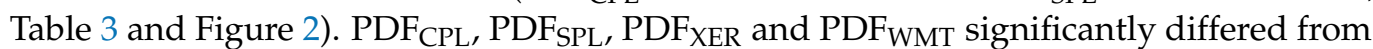
most ecoregions, whereas $\mathrm{PDF}_{\mathrm{NAP}}, \mathrm{PDF}_{\mathrm{TPL}}, \mathrm{PDF}_{\mathrm{NPL}}, \mathrm{PDF}_{\mathrm{SAP}}$ and PDF $\mathrm{UMW}_{\mathrm{W}}$, showed much less significant differences (Figure 2). Those $\mathrm{PDF}_{\text {eco }}$ were mostly all characterized by smaller sample sizes (respectively, $n=4,15,8,12$ or 2 ). Results from the ANOVA suggest a longitudinal gradient of impact, where $\mathrm{PDF}_{\text {eco }}$ are higher in the western part of the country and lower in the eastern part of the country (Figure 2). At the reservoir scale, PDF $_{\text {res }}$ varied from $-0.584 \pm 0.342$ (observation \pm pooled SD) to $0.924 \pm 0.464$, and $74 \%$ of the reservoirs showed a significant loss of macroinvertebrate taxa (Table A1).

Table 3. Table showing the mean native riverine richness for each ecoregion ( \pm standard deviation; SD), sample number from which mean native riverine richness was computed (n.riv), mean impacted reservoir richness for each ecoregion $( \pm \mathrm{SD}$ ), Potentially Disappeared Fraction of Species (PDF \pm SD and $\pm 95 \%$ confidence interval [CI]) values and the sample number (n.res) from which mean reservoir richness and PDF was calculated is also shown for the United States and the nine ecoregions. A positive PDF represents a loss of taxa, whereas a negative PDF represents a gain of taxa.

\begin{tabular}{cccccccccc}
\hline $\begin{array}{c}\text { Ecoregion or } \\
\text { Country }\end{array}$ & $\begin{array}{c}\text { Mean Nat. Riv. } \\
\text { Richness }\end{array}$ & \pm SD & n.riv & $\begin{array}{c}\text { Mean Imp. } \\
\text { Res. Richness }\end{array}$ & \pm SD & $\begin{array}{c}\text { PDF } \\
\mathbf{m}^{\mathbf{2}} \cdot \mathbf{y r} / \mathbf{m}^{\mathbf{2}} \cdot \mathbf{y r}\end{array}$ & $\pm \mathbf{S D}$ & $\pm \mathbf{9 5} \% \mathbf{C I}$ & $\mathbf{n . r e s}$ \\
\hline USA & 35.9 & 15.5 & 2062 & 25.7 & 10.4 & 0.284 & 0.168 & 0.028 \\
CPL & 28.4 & 16.6 & 327 & 32.9 & 7.9 & -0.158 & -0.100 & -0.059 & 134 \\
SPL & 26.1 & 13.1 & 176 & 26.7 & 11.8 & -0.021 & -0.014 & -0.006 & 24 \\
NAP & 46.0 & 13.8 & 225 & 39.8 & 9.4 & 0.135 & 0.052 & 0.051 & 4 \\
TPL & 32.0 & 12.9 & 209 & 27.5 & 7.7 & 0.141 & 0.069 & 0.035 \\
NPL & 29.4 & 10.1 & 179 & 23.5 & 6.6 & 0.202 & 0.090 & 0.062 & 8 \\
SAP & 45.8 & 15.1 & 344 & 35.9 & 8.8 & 0.216 & 0.089 & 0.050 & 12 \\
UMW & 39.3 & 12.7 & 167 & 27.5 & 3.5 & 0.301 & 0.105 & 0.145 & 2 \\
\hline
\end{tabular}


Table 3. Cont.

\begin{tabular}{cccccccccc}
\hline $\begin{array}{c}\text { Ecoregion or } \\
\text { Country }\end{array}$ & $\begin{array}{c}\text { Mean Nat. Riv. } \\
\text { Richness }\end{array}$ & \pm SD & n.riv & $\begin{array}{c}\text { Mean Imp. } \\
\text { Res. Richness }\end{array}$ & \pm SD & $\begin{array}{c}\text { PDF } \\
\mathbf{m}^{\mathbf{2}} \cdot \mathbf{y r} / \mathbf{m}^{\mathbf{2}} \cdot \mathbf{y r}\end{array}$ & $\pm \mathbf{S D}$ & $\pm \mathbf{9 5}$ CI & n.res \\
\hline XER & 31.0 & 11.6 & 213 & 19.7 & 7.9 & 0.363 & 0.199 & 0.073 \\
WMT & 39.8 & 12.0 & 222 & 21.3 & 8.6 & 0.464 & 0.235 & 0.086 & 29 \\
\hline
\end{tabular}

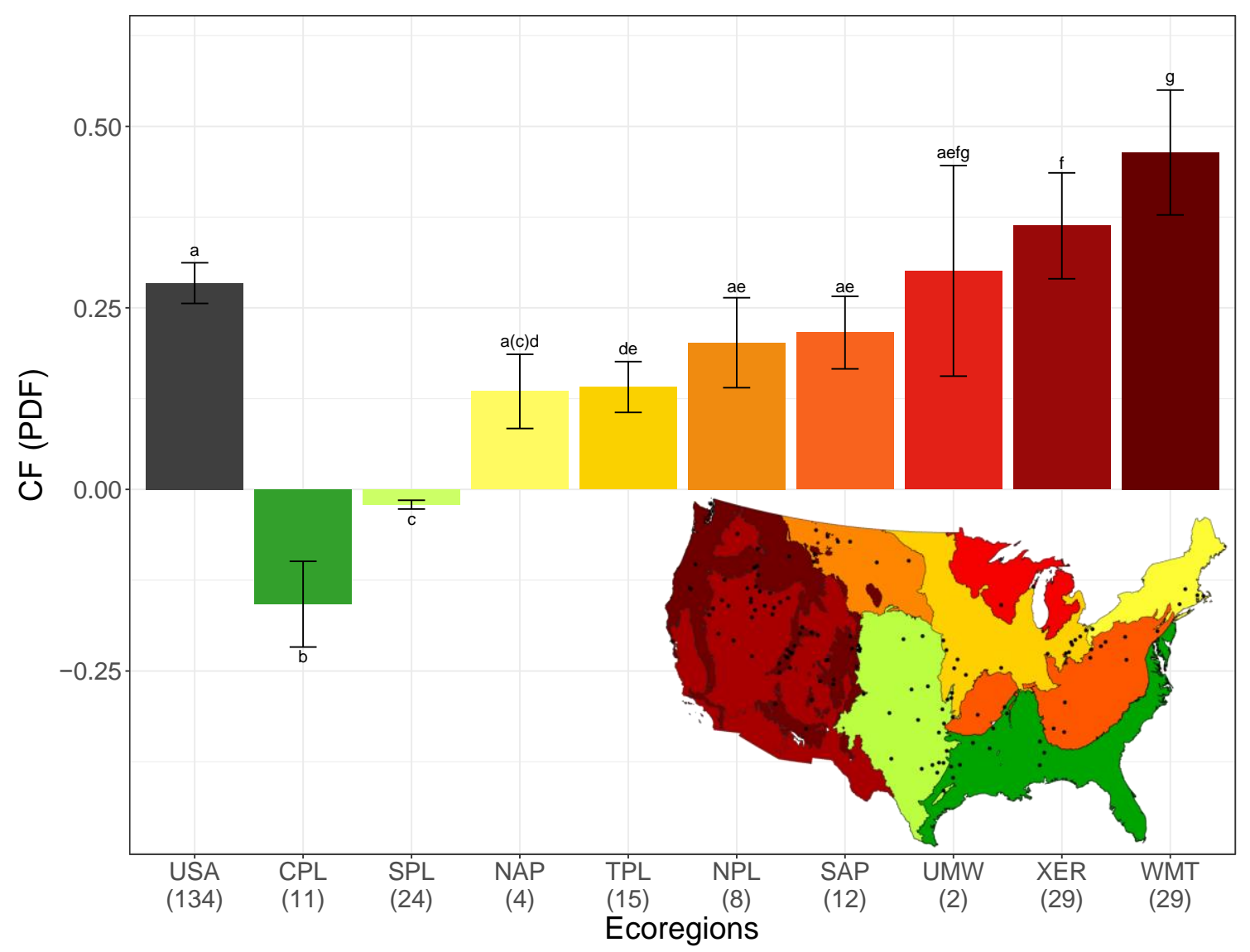

Figure 2. Barplot showing a mean characterization factor (CF) in Potentially Disappeared Fraction of species (PDF $\pm 95 \%$ confidence interval; CI) at the United States (USA) level ( $\mathrm{PDF}_{\text {usa }}$ shown in dark grey) and at the ecoregion level (PDF $\mathrm{eco}$

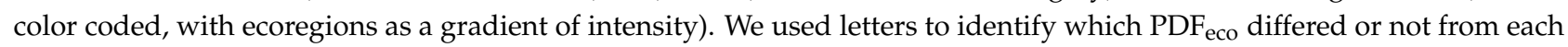
other. When two bars share a letter, they are not significantly different from each other and marginally not significantly different from each other when the letter is in parentheses. A positive PDF represents a loss of taxa, whereas a negative PDF represents a gain of taxa. Ecoregions are abbreviated as follows; Coastal Plains (CPL), Northern Appalachians (NAP), Northern Plains (NPL), Southern Appalachians (SAP), Southern Plains (SPL) Temperate Plains (TPL), Upper Midwest (UMW), Western Mountains (WMT) and Xeric (XER). Sample number from which mean reservoir richness and PDFs were calculated is also shown on the $\mathrm{x}$ axis in parentheses. For specific values, refer to Table 3.

\subsection{Variables Explaining the Variation in $P D F_{\text {res }}$}

At the reservoir scale, the four matrices (spatial, physical, chemical, and human) explained approximately $51 \%$ of the total variation in $\mathrm{PDF}_{\text {res }}$ (variation partitioning; Figure 3; Table A2). Approximately $46 \%$ of the variation was explained by the combined effects of the spatial (ecoregion) and physical (elevation and surface area) matrices. Spatial matrix (ecoregion) explained $25 \%$ of the variation, over which $24 \%$ of this variation was shared with the physical matrix (elevation and surface area), 11\% was shared with the chemical matrix (pH and trophic state), and $8 \%$ was shared with the human matrix (presence of lawn and road adjacent to the reservoir shoreline; Figure 3). The physical matrix explained $45 \%$ of the variation. Elevation and surface area alone (variation not shared with the other 
matrices) explained $15 \%$ of the variation. The chemical and human matrices explained, respectively, $18 \%$ and $14 \%$ of the variation.

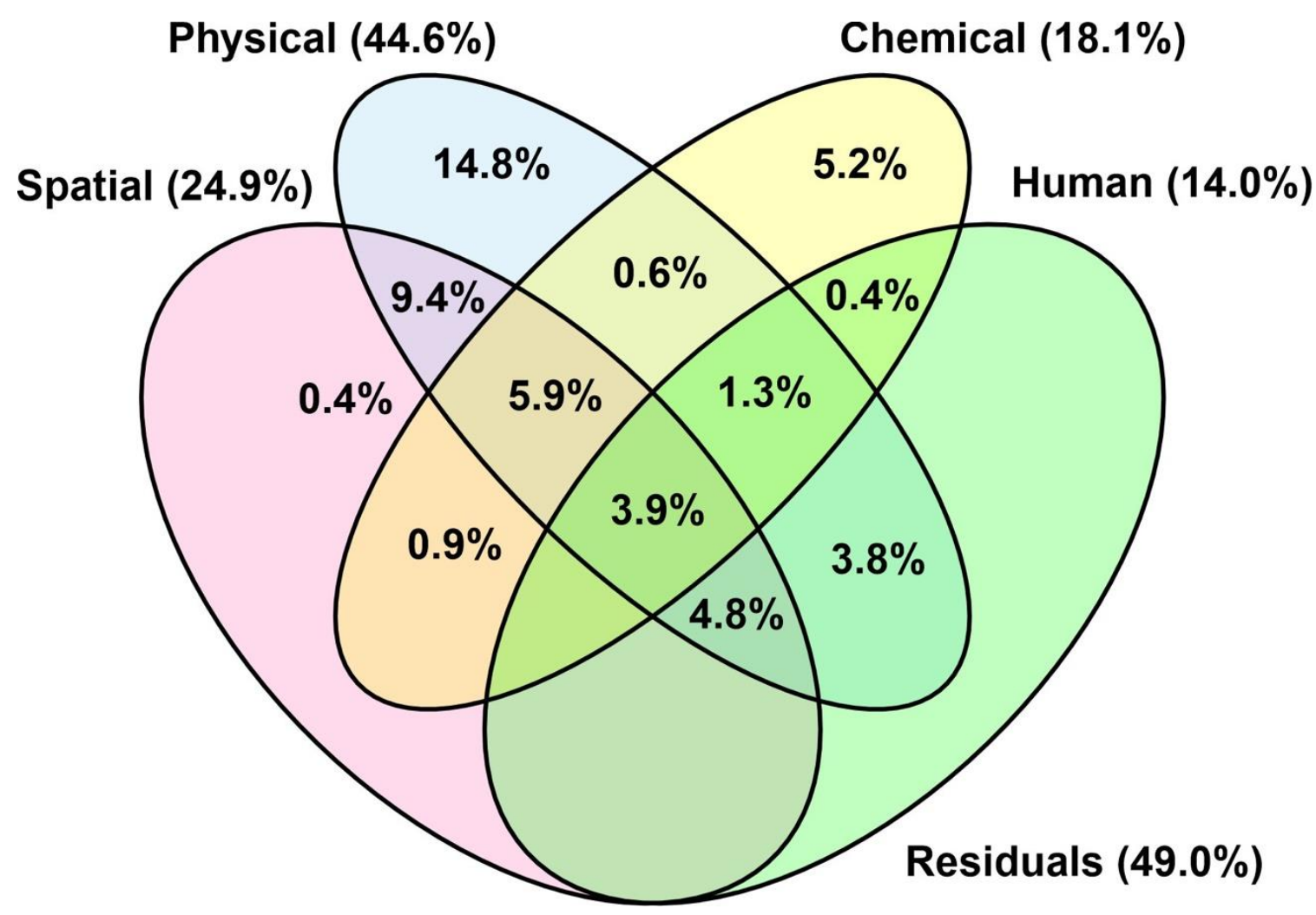

Figure 3. Venn diagram showing variation partitioning of a response matrix (Potentially Disappeared Fraction of species; PDF) explained by four matrices, that is spatial matrix (ecoregion; ECO), physical matrix (elevation; ELE, and, surface area; AREA), chemical matrix (trophic state; T.S. and, $\mathrm{pH}$ ) and human matrix (influence of lawns; LAWN, and influence of roads; ROAD). Values $<0$ not shown.

\section{3. $P D F_{\text {res }}$ Empirical Model}

According to the empirical model (Equations (4) and (5); Figure 4), almost $50 \%$ of the observed variation in $\mathrm{PDF}_{\text {res }}$ (partial $\mathrm{R}^{2}$ adj $=0.49 ; p<0.001 ; n=134$ ) was explained by elevation $(35 \%)$, trophic state (either oligotrophic or eutrophic; $4 \%$ ), and reservoir surface area $(10 \%)$. No more than $50 \%$ of the variation explained is acceptable in ecology disciplines, since there is substantial environmental variation that cannot be accounted for, unless specifically sampled for. $\mathrm{PDF}_{\text {res }}$ was positively related to reservoir elevation, where higher elevation was associated to higher $\mathrm{PDF}_{\text {res }}$ (Figure 4). $\mathrm{PDF}_{\text {res }}$ was negatively related to eutrophication status. Oligotrophic reservoirs $(<10 \mu \mathrm{g} / \mathrm{L}$ total phosphorus) had higher $\mathrm{PDF}_{\text {res }}$ than eutrophic reservoirs $(>10 \mu \mathrm{g} / \mathrm{L}$ total phosphorus). As for reservoir surface area, there was a positive relationship between reservoir surface area and $\mathrm{PDF}_{\text {res, }}$, where bigger reservoirs had a higher $\mathrm{PDF}_{\text {res }}$ than smaller ones (Figure 4). To summarize, large oligotrophic reservoirs located at higher elevation were most likely to have higher macroinvertebrate $\mathrm{PDF}_{\text {res }}$.

$$
\begin{aligned}
\mathrm{PDF}_{\text {res }[\text { OLIGOTROPHIC }]=} & -0.129( \pm 0.109)+0.013( \pm 0.002) \cdot \operatorname{sqrt}(\mathrm{ELE})+0.170( \pm 0.043) \cdot \log _{10}(\mathrm{AREA}) \\
& \text { Values in parentheses are SE of the estimate } \\
\mathrm{PDF}_{\text {res }[\text { EUTROPHIC }]=-} & 0.454( \pm 0.102)+0.013( \pm 0.002) \cdot \operatorname{sqrt}(\mathrm{ELE})+0.170( \pm 0.043) \cdot \log _{10}(\mathrm{AREA})
\end{aligned}
$$




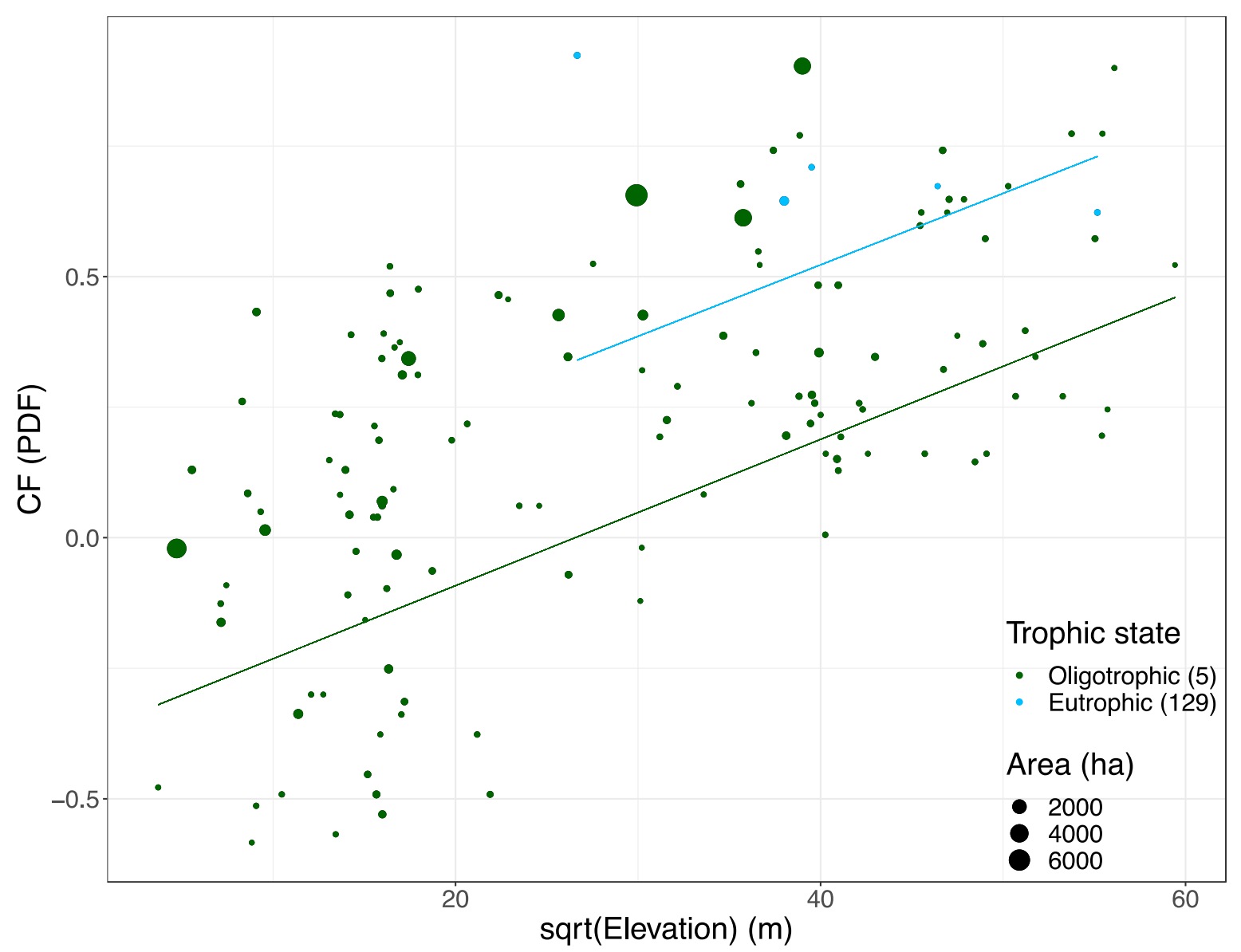

Figure 4. Graphical representation of our empirical model showing the relationship between characterization factors (CF) in Potentially Disappeared Fraction of species (PDF), reservoir elevation in meters and square root-transformed (m; ELE) and trophic state (oligotrophic [ $<10 \mu \mathrm{g} / \mathrm{L}$ total phosphorus] or eutrophic [ $>10 \mu \mathrm{g} / \mathrm{L}$ total phosphorus]; T.S.). Trophic state is color coded (sample number shown in parentheses) and point size is representative of reservoir surface area in hectares (ha; AREA).

\section{Discussion}

From the examination of 134 reservoirs of varied usages (flood control $[n=6]$, hydropower [ $n=2]$, recreational [ $n=23]$, soil erosion prevention [ $n=5]$, transport $[n=2]$, water supply [ $n=49]$ and unknown [ $n=47])$ and 2062 rivers and streams across the continental United States, our results showed a general loss of approximately $28 \%\left(\mathrm{PDF}_{\mathrm{usa}}\right)$ of macroinvertebrate taxa following reservoir occupation at the scale of the United States. $\mathrm{PDF}_{\text {eco }}$ also varied across ecoregions. Almost $25 \%$ of the total variation observed in $\mathrm{PDF}_{\text {res }}$ was explained by the nine ecoregions, pressing the need for regionalized CFs. We provided evidence that the empirical PDFs for macroinvertebrates were consistent and uniform across the three spatial scales (macroinvertebrate taxa loss at the scale of the country; $\mathrm{PDF}_{\text {usa, }}$, the majority of ecoregions; $\mathrm{PDF}_{\text {eco }}$, and most reservoirs; $\mathrm{PDF}_{\text {res }}$ ). Overall, the empirical PDFs derived in this study can be used as CFs in the LCA framework to evaluate the potential impact of reservoir occupation on the ecosystem quality AoP for a specific reservoir $\left(\mathrm{PDF}_{\text {res }}\right)$, within a given ecoregion $\left(\mathrm{PDF}_{\mathrm{eco}}\right)$ or over the United States $\left(\mathrm{PDF}_{\mathrm{usa}}\right)$. Potential impact scores expressed in PDF. $\mathrm{m}^{2} \cdot \mathrm{yr}$ can be calculated multiplying PDF by the area-time occupied by the reservoir for a given product or service. We also provided a simple empirical model based on three explanatory variables (elevation, trophic state and reservoir surface area) that explained $49 \%$ of the variation in macroinvertebrate $\mathrm{PDF}_{\text {res }}$. Reservoirs at higher elevation, with lower levels of eutrophication and bigger surface area had higher $\mathrm{PDF}_{\text {res. }}$. This empirical model could be used by LCA practitioners to interpolate 
CFs based on few explanatory variables. However, we did not test the transferability of our model to other countries, or to reservoirs outside of the ranges of application of this model (elevation between 13 and 3531 meters [m] and area between 2 and 6560 hectares [ha] for eutrophic reservoirs, and elevation between 711 and $3044 \mathrm{~m}$ and area between 12 and 408 ha for oligotrophic reservoirs; specific regression lines in Figure 4).

\subsection{United States Taxa Loss and Regionalization}

At the scale of the United States, $28 \%$ of macroinvertebrate taxa disappeared following reservoir occupation. This result suggests that reservoir occupation does affect the rate of change in macroinvertebrate richness, and this is consistent with the literature estimates of the impacts of hydropower on macroinvertebrate richness across the world [17-26]. Presently, there is still no macroinvertebrate CF (PDF) available to assess potential impacts of reservoir occupation on ecosystems biodiversity associated to a product or service in LCA. Our research provides the first empirically derived multi-scale macroinvertebratebased PDF values to the LCA community and fills in an important gap in this field of research. Our PDFs, in complement to fish-based PDFs (see Turgeon et al., [35] and Dorber et al. [36]), could also allow for a more holistic approach, the generation of a multi-phyla $\mathrm{CF}$, which would be more robust and representative of the ecosystem impacts. The $\mathrm{PDF}_{\text {usa }}$ covers a large geographical range across the United States, with substantial ecoregion variability. For this reason, we suggest using $\mathrm{PDF}_{\text {eco }}$ (at the ecoregion level). This study also showed that there was a significant difference between $\mathrm{PDF}_{\text {eco }}$ and the presence of a longitudinal gradient of impact with higher $\mathrm{PDF}_{\mathrm{eco}}$ in the west. According to these results, reservoir occupation, regardless of its purpose, would have higher impacts in the western ecoregions of the United States. The WMT ecoregion is characterized by its mountains and valleys landscapes and a sub-arid to arid climate, where it gets rather humid and cold at higher elevation [54]. The XER ecoregion has lots of ephemeral rivers, relatively limited surface water supply and its climate varies widely from a xeric warm and dry environment to temperate conditions [54]. These types of conditions usually favor specialist taxa, which are highly adapted to their environment, and are known to be particularly sensitive to human impacts [63-65]. Our results support these observations because $\mathrm{PDF}_{\text {eco }}$ are higher in those ecoregions, meaning that reservoir occupation has higher impacts on ecosystem quality and biodiversity. The observed spatial differentiation and longitudinal gradient of impact justify the need for regionalized CFs, which would improve the accuracy and robustness of LCA.

\subsection{Elevation, Trophic State and Reservoir Surface Area}

In our empirical model, a combination of elevation, trophic state and reservoir surface area explained most the variation in $\mathrm{PDF}_{\text {res }}$. As reservoirs increase in elevation, their $\mathrm{PDF}_{\text {res }}$ also increase. High elevation ecosystems support smaller, isolated, prone-to-extinction populations, as well as a higher proportion of more vulnerable taxa, which makes these alpine ecosystems more sensitive to biodiversity loss following human impacts [66]. Oligotrophic reservoirs, because of their low productivity [67], host relatively lower richness compared to mesotrophic/eutrophic reservoirs [68]. Thus, they are more sensitive to taxa loss (loss of one taxon over a few taxa is relatively more important than over multiple taxa). This is reflected in our results, oligotrophic reservoirs have higher $\mathrm{PDF}_{\text {res }}$ than eutrophic ones. $\mathrm{PDF}_{\text {res }}$ were also shown to be higher in reservoirs with a larger surface area. This result is not clearly supported by the literature. Lake size is one of multiple key factors affecting reservoir biodiversity [69-71], bigger reservoirs are more productive and more heterogeneous in terms of potential habitats and thus support more richness (biodiversity; SAR) [72-74]. One could then imagine that high biodiversity ecosystems would be less vulnerable to taxa loss proportionally speaking, which is not the case here. It is not clear to us as to why our larger reservoirs showed higher $\mathrm{PDF}_{\text {res }}$ because they did not share similar water usage, neither were they specifically located at high elevation, nor 
clustered in a specific ecoregion (Figure 5). This pattern could be biased by the unbalanced sample size.
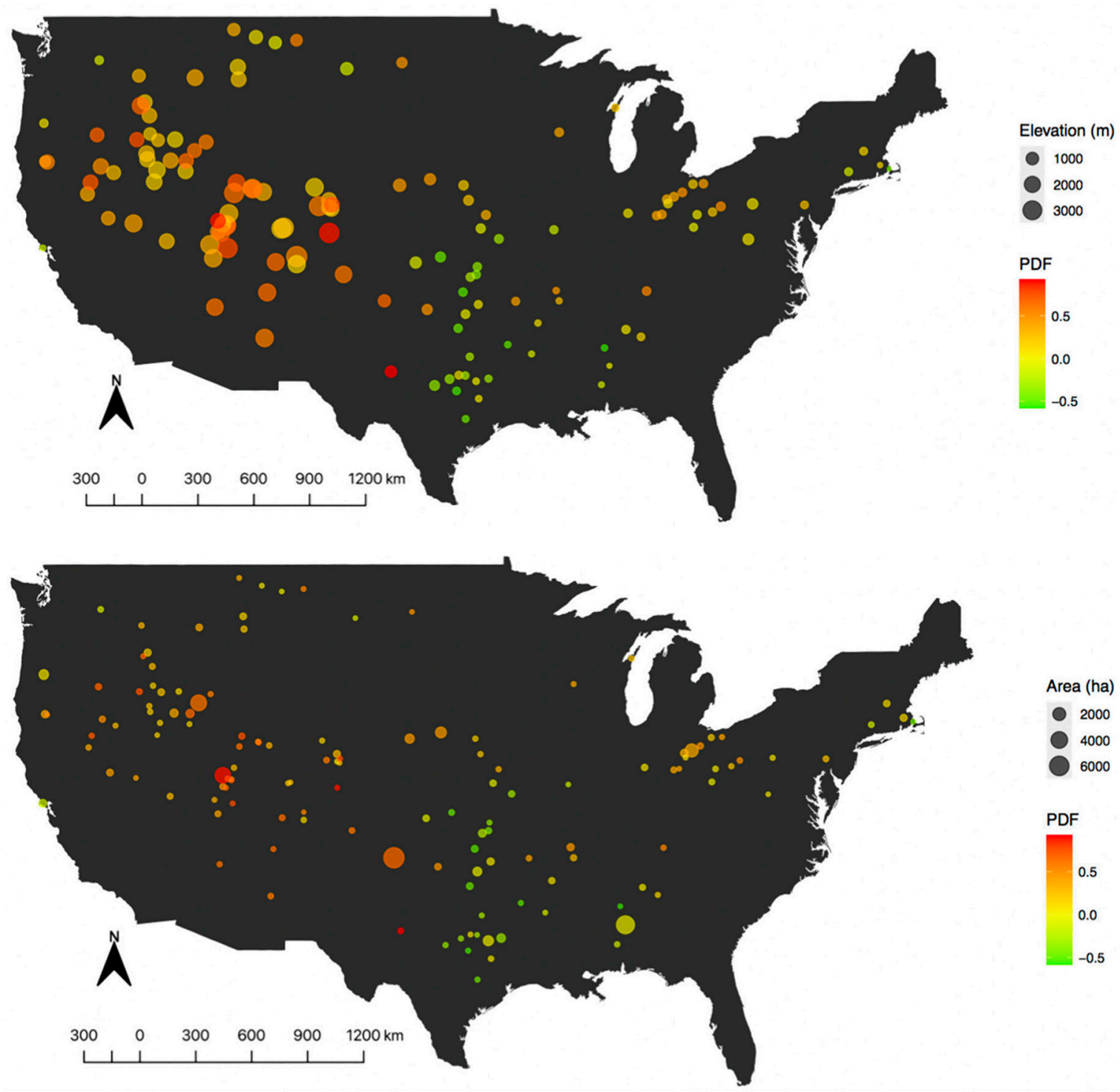

Figure 5. Heatmaps of Potentially Disappeared Fraction of species (PDF), elevation in meters (m; ELE) and surface area in hectares (ha; AREA) of reservoir is proportional to the point size.

Regarding the remaining $49 \%$ of unexplained variation in the variation partitioning, it would have been useful to have data related to flow regime dynamics in each reservoir as they are known to influence macroinvertebrates. It would have also been useful to have habitat-specific characteristics related to each sample, such as granulometry and macrophyte coverage, two variables known to strongly influence the abundance and biodiversity of macroinvertebrate communities. From an ecological point of view, our observations were mostly supported by the literature. The empirical model was built with a specific purpose in mind: to provide LCA practitioners with a simple model, based on a few explanatory variables. Collecting macroinvertebrate richness data is time consuming and expensive, as well as demanding in terms of expertise for identification. The empirical model allows to interpolate robust $\mathrm{PDF}_{\text {res }}( \pm$ quantified error) for a specific reservoir using readily available information such as elevation, reservoir surface area, and trophic state. 


\subsection{Limitations}

Five limitations can influence the strength of our results. First, we defined richness as the number of native riverine taxa. We did not account for the potential gain of lentic-specific taxa following reservoir occupation, therefore our PDFs are considered conservative. When a river is transformed and occupied by a reservoir, some native riverine taxa are lost, and some lentic taxa can be gained. Thus, one should be careful when interpreting these gain in taxa (lentic, exotic or non-native invasive taxa) as they might not necessarily represent an ecosystem improvement [75]. Based on the Habitat Diversity Hypothesis (HDH) [76], where diversity of taxa is directly related to the diversity of habitats, lotic environments should be more diversified than lentic environments (reservoirs). Because of their narrowness and longitude, rivers run through a greater range of geological formations, as well as geographical regions, per unit of surface area and vary more in terms of substrate, water temperature and flow dynamics than lentic environment of comparable depth and size [77-79]. Thus, the higher environmental variability and productivity, as well as the presence of microhabitat heterogeneity in rivers likely support more taxa per surface area [79-81]. We could then assume that even after a lotic environment is transformed into and a lentic one, there would still be less taxa in the lentic environment. Moreover, gain of lentic taxa after reservoir occupation is often considered a misleading argument because the littoral zone in reservoirs is less complex, differs in physico-chemical conditions [82] and is generally negatively affected by varying water levels. These characteristics can affect the productivity of littoral areas, which are crucial to reservoir productivity, and can, in turn, affect its biodiversity. This further reinforces the potential overestimation of our PDFs. A second limitation of this study is that our CF is not independent from other impact categories, namely eutrophication. Because trophic state was defined as a significant variable to explain PDF, we had to incorporate this information in our model. In the LCA framework, eutrophication is already taken into account and thus, using it in our model could cause some bias in the overall compilation of impacts (double counting). A third limitation from this study is the use of space-for-time substitution approach. We do not have a Before-After Control-Impact study design (BACI). Data on river and stream richness before reservoir occupation are not available so our results, and suggested PDFs, must be interpreted with caution. A fourth limitation of this study is the use of taxa richness (number of taxa) only to evaluate the impacts of reservoir occupation on biodiversity. It would be optimal to also assess changes in community composition (number of taxa and their respective abundance). However, given that the current LCA framework (for example, IMPACT World +) [83] uses PDF (based on changes in taxa richness) and does not yet include impacts on community composition, it is not yet possible to include the impacts on community composition in the LCA framework. Doing so would also face important challenges regarding data availability to compute such a metric. Finally, the fifth limitation is that the performance of the empirical model has not been evaluated outside the USEPA-NLA dataset. Such evaluation through case studies and independent datasets should be performed to test the robustness of its predictive power.

\section{Conclusions}

Using a space-for-time substitution approach, we showed that the transformation and occupation of a riverbed by a reservoir resulted in a loss of $28 \%$ of macroinvertebrate taxa in the United States. This loss of richness also varied across ecoregions, pressing the need for regionalized PDFs. Patterns were consistent across scales (the United States, nine ecoregions and 134 reservoirs), where we observed a general loss of macroinvertebrate richness. These PDFs fill in an important gap in LCA, enabling the assessment of reservoir occupation impacts (involved in several common activities in the LCA of a product or service, such as hydropower, irrigation, drinking water, transportation or recreation) onto ecosystem quality. We also derived an empirical model to explain and interpolate PDFs as a function of three explanatory variables: reservoir elevation, trophic state and surface area. Our study generated PDFs using robust empirical richness data, rather than theoretical 
curves (SARs or SDRs), which is a novel approach in this specific branch of LCA. Our PDF also considered a new type of organism, macroinvertebrates, that can be used to complement the information already generated for fish, thus improving the robustness and representation of biodiversity impacts characterization in the LCA framework. Despite some highlighted limitations, the empirical CFs developed through this study constitute a strong contribution to assess the impacts of reservoir occupation on the ecosystem quality AoP. Natural follow ups to this study would be to integrate macroinvertebratebased CFs with fish-based CFs from Turgeon et al. [35] to improve the characterization of impacts on ecosystem quality and to evaluate the accuracy of the empirical model to other geographical contexts.

Author Contributions: Conceptualization, G.T.; data curation, G.T.; formal analysis, G.T.; funding acquisition, M.M.; methodology, G.T.; project administration, M.M.; supervision, D.B., C.B. and M.M.; validation, K.T. and F.V.; visualization, G.T.; writing—original draft, G.T.; writing-review and editing, G.T., K.T., F.V., D.B., C.B. and M.M. All authors have read and agreed to the published version of the manuscript.

Funding: This research was funded by the Natural Sciences and Engineering Research Council of Canada (NSERCC), the Fonds Québécois de la Recherche sur la Nature et les Technologies (FQRNT), Fondation Polytechnique and Hydro-Québec, as well as the Institut de l'Environnement, le Développement Durable et l'Économie Circulaire (EDDEC) and Banque TD. Funding sources had no involvement in the study design, data collection, analysis and interpretation, writing process and the decisions regarding manuscript submission for eventual journal publication.

Institutional Review Board Statement: Not applicable.

Informed Consent Statement: Not applicable.

Data Availability Statement: The data presented in this study are available within this article and publicly available through the USEPA-NARS website (https:/ / www.epa.gov/national-aquaticresource-surveys (accessed on 2 March 2021)).

Acknowledgments: We thank the three anonymous reviewers and the editor for their thorough revisions of this manuscript and their numerous helpful comments and suggestions. Their feedbacks played an important role in improving the quality of this manuscript. We also thank Andrea Gideon who provided valuable feedbacks and corrections regarding the overall English style and language description of this article. Finally, we thank the CIRAIG_Polytechnique Montréal for covering the Open Access publication fees.

Conflicts of Interest: The authors declare no conflict of interest. 


\section{Appendix A}

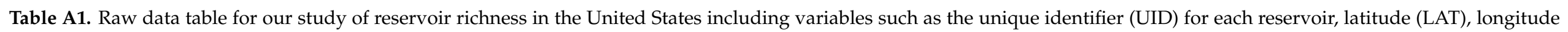

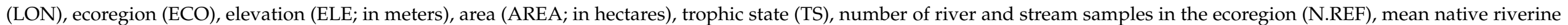

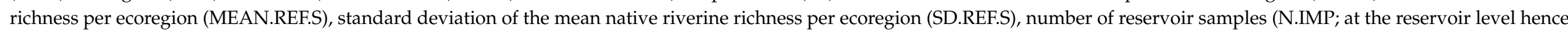

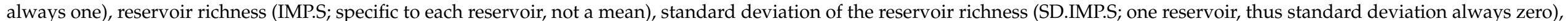

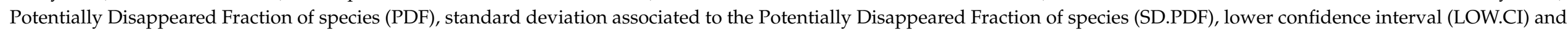
higher confidence interval (UP.CI).

\begin{tabular}{|c|c|c|c|c|c|c|c|c|c|c|c|c|c|c|c|c|}
\hline UID & LAT & LON & ECO & ELE & AREA & TS & N.REF & MEAN.REF.S & SD.REF.S & N.IMP & IMP.S & SD.IMP.S & PDF & SD.PDF & LOW.CI & UP.CI \\
\hline 6243 & 38.507965 & -94.673265 & TPL & 295.8 & 110.0 & EUT & 209 & 32.0 & 12.9 & 1 & 42 & 0 & -0.314 & 0.126 & -0.562 & -0.066 \\
\hline 6252 & 40.111767 & -75.861530 & SAP & 186.7 & 63.2 & EUT & 344 & 45.8 & 15.1 & 1 & 35 & 0 & 0.236 & 0.078 & 0.083 & 0.388 \\
\hline 6267 & 31.621546 & -88.353739 & CPL & 50.8 & 32.6 & EUT & 327 & 28.4 & 16.6 & 1 & 32 & 0 & -0.126 & 0.074 & -0.271 & 0.019 \\
\hline 6270 & 35.174388 & -99.077489 & SPL & 499.9 & 141.5 & EUT & 176 & 26.1 & 13.1 & 1 & 14 & 0 & 0.465 & 0.233 & 0.007 & 0.922 \\
\hline 6281 & 35.285013 & -112.154163 & WMT & 2072.1 & 24.8 & EUT & 222 & 39.8 & 12.0 & 1 & 15 & 0 & 0.623 & 0.188 & 0.254 & 0.992 \\
\hline 6319 & 36.831633 & -104.226303 & WMT & 2066.2 & 44.2 & EUT & 222 & 39.8 & 12.0 & 1 & 16 & 0 & 0.598 & 0.181 & 0.243 & 0.952 \\
\hline 6342 & 39.994962 & -105.112227 & SPL & 1620.9 & 18.2 & EUT & 176 & 26.1 & 13.1 & 1 & 26 & 0 & 0.006 & 0.003 & 0.000 & 0.011 \\
\hline 6404 & 39.638354 & -95.456811 & TPL & 321.7 & 26.9 & EUT & 209 & 32.0 & 12.9 & 1 & 22 & 0 & 0.312 & 0.126 & 0.066 & 0.558 \\
\hline 6437 & 39.000154 & -95.779648 & TPL & 350.6 & 101.9 & EUT & 209 & 32.0 & 12.9 & 1 & 34 & 0 & -0.064 & 0.026 & -0.114 & -0.013 \\
\hline 6451 & 40.161787 & -79.052384 & SAP & 551.9 & 18.2 & EUT & 344 & 45.8 & 15.1 & 1 & 43 & 0 & 0.061 & 0.020 & 0.022 & 0.101 \\
\hline 6481 & 39.484355 & -118.723571 & XER & 1202.0 & 164.1 & EUT & 213 & 31.0 & 11.6 & 1 & 19 & 0 & 0.387 & 0.144 & 0.104 & 0.670 \\
\hline 6482 & 41.928985 & -119.179002 & XER & 1678.2 & 100.3 & EUT & 213 & 31.0 & 11.6 & 1 & 16 & 0 & 0.484 & 0.181 & 0.129 & 0.838 \\
\hline 6501 & 35.980828 & -108.931643 & WMT & 2290.2 & 15.4 & EUT & 222 & 39.8 & 12.0 & 1 & 14 & 0 & 0.648 & 0.196 & 0.264 & 1.032 \\
\hline 6525 & 35.992932 & -96.873677 & SPL & 255.6 & 177.7 & EUT & 176 & 26.1 & 13.1 & 1 & 40 & 0 & -0.530 & 0.266 & -1.051 & -0.009 \\
\hline 6550 & 34.953616 & -96.718159 & SPL & 281.1 & 533.1 & EUT & 176 & 26.1 & 13.1 & 1 & 27 & 0 & -0.033 & 0.016 & -0.065 & -0.001 \\
\hline 6556 & 35.412203 & -95.929276 & SPL & 201.3 & 204.3 & EUT & 176 & 26.1 & 13.1 & 1 & 25 & 0 & 0.044 & 0.022 & 0.001 & 0.087 \\
\hline 6570 & 37.655565 & -98.260986 & SPL & 479.3 & 56.8 & EUT & 176 & 26.1 & 13.1 & 1 & 39 & 0 & -0.492 & 0.247 & -0.975 & -0.008 \\
\hline 6575 & 40.723819 & -109.183908 & XER & 2184.0 & 43.3 & EUT & 213 & 31.0 & 11.6 & 1 & 21 & 0 & 0.322 & 0.120 & 0.086 & 0.558 \\
\hline 6606 & 37.390887 & -99.784838 & SPL & 685.8 & 127.3 & EUT & 176 & 26.1 & 13.1 & 1 & 28 & 0 & -0.071 & 0.036 & -0.141 & -0.001 \\
\hline 6617 & 41.757410 & -115.722027 & XER & 2089.2 & 23.6 & EUT & 213 & 31.0 & 11.6 & 1 & 26 & 0 & 0.161 & 0.060 & 0.043 & 0.279 \\
\hline 6618 & 41.198060 & -115.892296 & XER & 1814.2 & 5.0 & EUT & 213 & 31.0 & 11.6 & 1 & 26 & 0 & 0.161 & 0.060 & 0.043 & 0.279 \\
\hline 6622 & 31.889172 & -97.702492 & SPL & 290.0 & 20.7 & EUT & 176 & 26.1 & 13.1 & 1 & 35 & 0 & -0.339 & 0.170 & -0.672 & -0.005 \\
\hline 6668 & 36.823001 & -96.047588 & SPL & 230.6 & 103.5 & EUT & 176 & 26.1 & 13.1 & 1 & 38 & 0 & -0.453 & 0.228 & -0.899 & -0.007 \\
\hline 6695 & 36.705443 & -96.419109 & TPL & 266.8 & 325.4 & EUT & 209 & 32.0 & 12.9 & 1 & 40 & 0 & -0.251 & 0.101 & -0.450 & -0.053 \\
\hline 6719 & 38.398162 & -115.117053 & XER & 1574.3 & 72.3 & EUT & 213 & 31.0 & 11.6 & 1 & 23 & 0 & 0.258 & 0.096 & 0.069 & 0.446 \\
\hline 6731 & 41.701690 & -113.959671 & XER & 1622.6 & 10.3 & EUT & 213 & 31.0 & 11.6 & 1 & 26 & 0 & 0.161 & 0.060 & 0.043 & 0.279 \\
\hline 6735 & 32.944430 & -96.453752 & SPL & 146.0 & 13.8 & EUT & 176 & 26.1 & 13.1 & 1 & 34 & 0 & -0.300 & 0.151 & -0.596 & -0.005 \\
\hline
\end{tabular}


Table A1. Cont.

\begin{tabular}{|c|c|c|c|c|c|c|c|c|c|c|c|c|c|c|c|c|}
\hline UID & LAT & LON & ECO & ELE & AREA & TS & N.REF & MEAN.REF.S & SD.REF.S & N.IMP & IMP.S & SD.IMP.S & PDF & SD.PDF & LOW.CI & UP.CI \\
\hline 6742 & 47.761716 & -108.432829 & NPL & 912.2 & 4.3 & EUT & 179 & 29.4 & 10.1 & 1 & 30 & 0 & -0.019 & 0.007 & -0.032 & -0.006 \\
\hline 6753 & 39.931042 & -104.973296 & SPL & 1600.5 & 9.2 & EUT & 176 & 26.1 & 13.1 & 1 & 20 & 0 & 0.235 & 0.118 & 0.004 & 0.466 \\
\hline 6762 & 33.516175 & -94.125132 & CPL & 82.4 & 17.1 & EUT & 327 & 28.4 & 16.6 & 1 & 43 & 0 & -0.513 & 0.301 & -1.103 & 0.076 \\
\hline 6774 & 46.826042 & -100.634208 & NPL & 523.4 & 3.9 & EUT & 179 & 29.4 & 10.1 & 1 & 16 & 0 & 0.456 & 0.157 & 0.149 & 0.764 \\
\hline 6795 & 38.997241 & -108.051180 & WMT & 3070.9 & 15.0 & EUT & 222 & 39.8 & 12.0 & 1 & 32 & 0 & 0.195 & 0.059 & 0.080 & 0.311 \\
\hline 6796 & 37.193346 & -95.988976 & SPL & 252.1 & 13.5 & EUT & 176 & 26.1 & 13.1 & 1 & 36 & 0 & -0.377 & 0.189 & -0.748 & -0.006 \\
\hline 6806 & 38.491412 & -79.314781 & SAP & 604.1 & 3.8 & EUT & 344 & 45.8 & 15.1 & 1 & 43 & 0 & 0.061 & 0.020 & 0.022 & 0.101 \\
\hline 6823 & 43.165878 & -115.652476 & XER & 997.2 & 163.9 & EUT & 213 & 31.0 & 11.6 & 1 & 24 & 0 & 0.225 & 0.084 & 0.060 & 0.390 \\
\hline 6869 & 38.847537 & -111.961390 & XER & 1589.5 & 93.2 & EUT & 213 & 31.0 & 11.6 & 1 & 16 & 0 & 0.484 & 0.181 & 0.129 & 0.838 \\
\hline 6874 & 39.036703 & -107.911131 & WMT & 3105.2 & 5.7 & EUT & 222 & 39.8 & 12.0 & 1 & 30 & 0 & 0.246 & 0.074 & 0.100 & 0.391 \\
\hline 6875 & 40.944919 & -106.011968 & XER & 2410.4 & 17.4 & EUT & 213 & 31.0 & 11.6 & 1 & 26 & 0 & 0.161 & 0.060 & 0.043 & 0.279 \\
\hline 6923 & 40.039991 & -81.013888 & SAP & 322.7 & 43.0 & EUT & 344 & 45.8 & 15.1 & 1 & 24 & 0 & 0.476 & 0.157 & 0.168 & 0.784 \\
\hline 6940 & 44.329096 & -116.184107 & WMT & 1507.0 & 71.6 & EUT & 222 & 39.8 & 12.0 & 1 & 29 & 0 & 0.271 & 0.082 & 0.110 & 0.431 \\
\hline 6944 & 39.169507 & -111.450721 & WMT & 2837.7 & 18.8 & EUT & 222 & 39.8 & 12.0 & 1 & 29 & 0 & 0.271 & 0.082 & 0.110 & 0.431 \\
\hline 6959 & 44.964115 & -116.463019 & WMT & 1453.0 & 211.4 & EUT & 222 & 39.8 & 12.0 & 1 & 32 & 0 & 0.195 & 0.059 & 0.080 & 0.311 \\
\hline 6966 & 39.142411 & -111.452546 & WMT & 2889.5 & 27.9 & EUT & 222 & 39.8 & 12.0 & 1 & 9 & 0 & 0.774 & 0.234 & 0.315 & 1.232 \\
\hline 6970 & 44.796705 & -116.732688 & WMT & 2154.4 & 12.4 & OLI & 222 & 39.8 & 12.0 & 1 & 13 & 0 & 0.673 & 0.204 & 0.274 & 1.072 \\
\hline 7020 & 38.078326 & -122.743359 & XER & 51.1 & 335.3 & EUT & 213 & 31.0 & 11.6 & 1 & 36 & 0 & -0.162 & 0.061 & -0.281 & -0.043 \\
\hline 7057 & 39.204737 & -111.668912 & WMT & 1789.8 & 24.8 & EUT & 222 & 39.8 & 12.0 & 1 & 30 & 0 & 0.246 & 0.074 & 0.100 & 0.391 \\
\hline 7097 & 38.788187 & -111.774878 & WMT & 2203.2 & 6.7 & EUT & 222 & 39.8 & 12.0 & 1 & 15 & 0 & 0.623 & 0.188 & 0.254 & 0.992 \\
\hline 7100 & 43.965218 & -122.683968 & WMT & 255.3 & 709.5 & EUT & 222 & 39.8 & 12.0 & 1 & 37 & 0 & 0.070 & 0.021 & 0.028 & 0.111 \\
\hline 7105 & 41.110516 & -82.083872 & NAP & 258.0 & 21.0 & EUT & 225 & 46.0 & 13.8 & 1 & 28 & 0 & 0.391 & 0.118 & 0.160 & 0.622 \\
\hline 7108 & 30.963438 & -95.903504 & CPL & 86.9 & 27.3 & EUT & 327 & 28.4 & 16.6 & 1 & 27 & 0 & 0.050 & 0.029 & -0.007 & 0.107 \\
\hline 7109 & 32.072696 & -97.129773 & SPL & 186.9 & 12.6 & EUT & 176 & 26.1 & 13.1 & 1 & 24 & 0 & 0.082 & 0.041 & 0.001 & 0.163 \\
\hline 7136 & 41.633291 & -118.389357 & XER & 1311.6 & 15.4 & EUT & 213 & 31.0 & 11.6 & 1 & 23 & 0 & 0.258 & 0.096 & 0.069 & 0.446 \\
\hline 7205 & 32.240254 & -101.313303 & SPL & 711.1 & 56.8 & OLI & 176 & 26.1 & 13.1 & 1 & 2 & 0 & 0.924 & 0.464 & 0.015 & 1.832 \\
\hline 7207 & 42.157825 & -122.607634 & WMT & 684.2 & 256.5 & EUT & 222 & 39.8 & 12.0 & 1 & 26 & 0 & 0.346 & 0.105 & 0.141 & 0.551 \\
\hline 7226 & 42.130013 & -122.478277 & WMT & 1344.3 & 4.4 & EUT & 222 & 39.8 & 12.0 & 1 & 19 & 0 & 0.522 & 0.158 & 0.213 & 0.832 \\
\hline 7228 & 34.227816 & -86.843449 & SAP & 247.0 & 73.0 & EUT & 344 & 45.8 & 15.1 & 1 & 44 & 0 & 0.039 & 0.013 & 0.014 & 0.065 \\
\hline 7229 & 40.631585 & -120.002870 & XER & 1329.5 & 37.1 & EUT & 213 & 31.0 & 11.6 & 1 & 20 & 0 & 0.354 & 0.132 & 0.095 & 0.614 \\
\hline 7232 & 40.703407 & -83.378745 & TPL & 269.7 & 102.7 & EUT & 209 & 32.0 & 12.9 & 1 & 17 & 0 & 0.468 & 0.189 & 0.099 & 0.838 \\
\hline 7276 & 41.168583 & -119.817451 & XER & 1560.8 & 28.9 & OLI & 213 & 31.0 & 11.6 & 1 & 9 & 0 & 0.710 & 0.265 & 0.190 & 1.229 \\
\hline 7294 & 39.056042 & -82.690673 & SAP & 211.5 & 65.1 & EUT & 344 & 45.8 & 15.1 & 1 & 47 & 0 & -0.026 & 0.009 & -0.043 & -0.009 \\
\hline 7304 & 31.587497 & -98.622503 & SPL & 448.8 & 27.8 & EUT & 176 & 26.1 & 13.1 & 1 & 36 & 0 & -0.377 & 0.189 & -0.748 & -0.006 \\
\hline
\end{tabular}


Table A1. Cont.

\begin{tabular}{|c|c|c|c|c|c|c|c|c|c|c|c|c|c|c|c|c|}
\hline UID & LAT & LON & ECO & ELE & AREA & TS & N.REF & MEAN.REF.S & SD.REF.S & N.IMP & IMP.S & SD.IMP.S & PDF & SD.PDF & LOW.CI & UP.CI \\
\hline 7306 & 39.241149 & -117.165818 & XER & 2255.5 & 5.8 & EUT & 213 & 31.0 & 11.6 & 1 & 19 & 0 & 0.387 & 0.144 & 0.104 & 0.670 \\
\hline 7325 & 40.337080 & -105.126694 & SPL & 1562.4 & 189.8 & EUT & 176 & 26.1 & 13.1 & 1 & 19 & 0 & 0.273 & 0.137 & 0.004 & 0.542 \\
\hline 7368 & 32.515869 & -87.861085 & CPL & 22.3 & 4731.5 & EUT & 327 & 28.4 & 16.6 & 1 & 29 & 0 & -0.021 & 0.012 & -0.044 & 0.003 \\
\hline 7375 & 33.364862 & -88.166880 & CPL & 78.1 & 5.6 & EUT & 327 & 28.4 & 16.6 & 1 & 45 & 0 & -0.584 & 0.342 & -1.254 & 0.086 \\
\hline 7392 & 34.534351 & -92.268826 & CPL & 74.1 & 105.8 & EUT & 327 & 28.4 & 16.6 & 1 & 26 & 0 & 0.085 & 0.050 & -0.013 & 0.182 \\
\hline 7402 & 34.284778 & -97.170972 & SPL & 245.4 & 160.7 & EUT & 176 & 26.1 & 13.1 & 1 & 39 & 0 & -0.492 & 0.247 & -0.975 & -0.008 \\
\hline 7405 & 40.328099 & -96.532001 & TPL & 425.9 & 32.1 & EUT & 209 & 32.0 & 12.9 & 1 & 25 & 0 & 0.218 & 0.088 & 0.046 & 0.390 \\
\hline 7459 & 33.882010 & -85.931618 & SAP & 171.0 & 18.1 & EUT & 344 & 45.8 & 15.1 & 1 & 39 & 0 & 0.148 & 0.049 & 0.052 & 0.244 \\
\hline 7471 & 46.040623 & -110.692175 & NPL & 1556.2 & 96.7 & EUT & 179 & 29.4 & 10.1 & 1 & 23 & 0 & 0.219 & 0.075 & 0.071 & 0.366 \\
\hline 7472 & 46.624624 & -110.738336 & NPL & 1672.9 & 150.7 & EUT & 179 & 29.4 & 10.1 & 1 & 25 & 0 & 0.151 & 0.052 & 0.049 & 0.252 \\
\hline 7533 & 43.078399 & -112.693659 & XER & 1338.8 & 21.3 & EUT & 213 & 31.0 & 11.6 & 1 & 14 & 0 & 0.548 & 0.205 & 0.147 & 0.949 \\
\hline 7572 & 40.372482 & -84.340110 & TPL & 291.8 & 327.1 & EUT & 209 & 32.0 & 12.9 & 1 & 22 & 0 & 0.312 & 0.126 & 0.066 & 0.558 \\
\hline 7579 & 39.608156 & -84.971507 & TPL & 254.8 & 72.8 & EUT & 209 & 32.0 & 12.9 & 1 & 21 & 0 & 0.343 & 0.138 & 0.072 & 0.614 \\
\hline 7643 & 39.706824 & -111.293369 & WMT & 2569.0 & 31.5 & EUT & 222 & 39.8 & 12.0 & 1 & 29 & 0 & 0.271 & 0.082 & 0.110 & 0.431 \\
\hline 7652 & 40.176639 & -84.265220 & TPL & 275.4 & 15.3 & EUT & 209 & 32.0 & 12.9 & 1 & 29 & 0 & 0.093 & 0.037 & 0.020 & 0.166 \\
\hline 7684 & 37.673281 & -107.112778 & WMT & 3530.5 & 2.1 & EUT & 222 & 39.8 & 12.0 & 1 & 19 & 0 & 0.522 & 0.158 & 0.213 & 0.832 \\
\hline 7713 & 46.118216 & -113.374640 & WMT & 1847.6 & 152.3 & EUT & 222 & 39.8 & 12.0 & 1 & 26 & 0 & 0.346 & 0.105 & 0.141 & 0.551 \\
\hline 7800 & 41.677573 & -73.144698 & NAP & 198.8 & 56.2 & EUT & 225 & 46.0 & 13.8 & 1 & 51 & 0 & -0.109 & 0.033 & -0.174 & -0.045 \\
\hline 7810 & 43.413998 & -119.410472 & XER & 1268.6 & 107.8 & EUT & 213 & 31.0 & 11.6 & 1 & 10 & 0 & 0.677 & 0.253 & 0.181 & 1.173 \\
\hline 7812 & 35.562459 & -93.637568 & SAP & 203.7 & 44.7 & EUT & 344 & 45.8 & 15.1 & 1 & 28 & 0 & 0.389 & 0.128 & 0.137 & 0.640 \\
\hline 8016 & 33.829304 & -109.090421 & WMT & 2403.4 & 48.4 & EUT & 222 & 39.8 & 12.0 & 1 & 17 & 0 & 0.573 & 0.173 & 0.233 & 0.912 \\
\hline 8121 & 36.067203 & -91.142428 & SAP & 82.7 & 222.6 & EUT & 344 & 45.8 & 15.1 & 1 & 26 & 0 & 0.432 & 0.143 & 0.153 & 0.712 \\
\hline 8144 & 35.583189 & -90.962941 & $\mathrm{CPL}$ & 69.0 & 95.9 & EUT & 327 & 28.4 & $\begin{array}{l}10.1 \\
16.6\end{array}$ & 1 & 21 & 0 & 0.261 & 0.153 & -0.038 & 0.560 \\
\hline 8151 & 41.088461 & -82.729015 & TPL & 249.8 & 80.7 & EUT & 209 & $\begin{array}{l}20.4 \\
32.0\end{array}$ & $\begin{array}{l}10.0 \\
12.9\end{array}$ & $\begin{array}{l}1 \\
1\end{array}$ & 26 & 0 & 0.187 & 0.075 & 0.039 & 0.334 \\
\hline 8184 & 40.055586 & -105.747080 & WMT & 3029.0 & 51.0 & EUT & 222 & 39.8 & 12.0 & 1 & 17 & 0 & 0.573 & 0.173 & 0.233 & 0.912 \\
\hline 8207 & 39.653475 & -82.473781 & SAP & 240.2 & 47.7 & EUT & 344 & 45.8 & 15.1 & 1 & 44 & 0 & 0.039 & 0.013 & 0.014 & 0.065 \\
\hline 8250 & 48.380621 & -110.985266 & NPL & 913.5 & 9.5 & EUT & 179 & 29.4 & 10.1 & 1 & 20 & 0 & 0.321 & 0.110 & 0.105 & 0.537 \\
\hline 8256 & 39.775971 & -81.522472 & SAP & 241.9 & 24.2 & EUT & 344 & 45.8 & 15.1 & 1 & 36 & 0 & 0.214 & 0.071 & 0.076 & 0.352 \\
\hline 8278 & 48.026569 & -109.623760 & NPL & 1128.8 & 9.8 & EUT & 179 & 29.4 & 10.1 & 1 & 27 & 0 & 0.083 & 0.028 & 0.027 & 0.138 \\
\hline 8325 & 37.416782 & -108.405651 & WMT & 2213.0 & 65.4 & EUT & 222 & 39.8 & 12.0 & 1 & 14 & 0 & 0.648 & 0.196 & 0.264 & 1.032 \\
\hline 8342 & 32.056309 & -96.731783 & SPL & 162.6 & 5.5 & EUT & 176 & 26.1 & 13.1 & 1 & 34 & 0 & -0.300 & 0.151 & -0.596 & -0.005 \\
\hline 8360 & 40.674602 & -110.970699 & WMT & 3043.5 & 39.4 & OLI & 222 & 39.8 & 12.0 & 1 & 15 & 0 & 0.623 & 0.188 & 0.254 & 0.992 \\
\hline 8395 & 40.889268 & -109.846108 & WMT & 2622.7 & 32.5 & EUT & 222 & 39.8 & 12.0 & 1 & 24 & 0 & 0.397 & 0.120 & 0.161 & 0.632 \\
\hline
\end{tabular}


Table A1. Cont.

\begin{tabular}{|c|c|c|c|c|c|c|c|c|c|c|c|c|c|c|c|c|}
\hline UID & LAT & LON & ECO & ELE & AREA & TS & N.REF & MEAN.REF.S & SD.REF.S & N.IMP & IMP.S & SD.IMP.S & PDF & SD.PDF & LOW.CI & UP.CI \\
\hline 8409 & 39.720767 & -86.720223 & TPL & 255.2 & 124.2 & EUT & 209 & 32.0 & 12.9 & 1 & 30 & 0 & 0.062 & 0.025 & 0.013 & 0.110 \\
\hline 8413 & 31.910344 & -95.301856 & CPL & 129.5 & 481.4 & EUT & 327 & 28.4 & 16.6 & 1 & 38 & 0 & -0.337 & 0.198 & -0.725 & 0.050 \\
\hline 8414 & 40.121695 & -104.945911 & SPL & 1509.8 & 24.7 & EUT & 176 & 26.1 & 13.1 & 1 & 6 & 0 & 0.771 & 0.387 & 0.012 & 1.529 \\
\hline 8427 & 44.698479 & -87.499926 & UMW & 179.8 & 35.5 & EUT & 167 & 39.3 & 12.7 & 1 & 30 & 0 & 0.237 & 0.077 & 0.087 & 0.388 \\
\hline 8435 & 47.876688 & -107.125232 & NPL & 758.1 & 13.8 & EUT & 179 & 29.4 & 10.1 & 1 & 14 & 0 & 0.524 & 0.180 & 0.171 & 0.878 \\
\hline 8437 & 42.646907 & -72.218497 & NAP & 195.1 & 138.4 & EUT & 225 & 46.0 & 13.8 & 1 & 40 & 0 & 0.130 & 0.039 & 0.053 & 0.206 \\
\hline 8443 & 41.812487 & -70.638227 & CPL & 13.7 & 10.8 & EUT & 327 & 28.4 & 16.6 & 1 & 42 & 0 & -0.478 & 0.280 & -1.027 & 0.071 \\
\hline 8487 & 39.661693 & -84.646207 & TPL & 287.3 & 7.1 & EUT & 209 & 32.0 & 12.9 & 1 & 20 & 0 & 0.374 & 0.151 & 0.079 & 0.670 \\
\hline 8494 & 41.989559 & -71.205066 & NAP & 30.9 & 202.4 & EUT & 225 & 46.0 & 13.8 & 1 & 40 & 0 & 0.130 & 0.039 & 0.053 & 0.206 \\
\hline 8495 & 46.941268 & -119.278530 & XER & 263.5 & 53.1 & EUT & 213 & 31.0 & 11.6 & 1 & 34 & 0 & -0.097 & 0.036 & -0.169 & -0.026 \\
\hline 8504 & 38.070619 & -111.375127 & WMT & 3074.1 & 11.2 & EUT & 222 & 39.8 & 12.0 & 1 & 9 & 0 & 0.774 & 0.234 & 0.315 & 1.232 \\
\hline 8614 & 36.044443 & -85.586295 & SAP & 269.0 & 30.2 & EUT & 344 & 45.8 & 15.1 & 1 & 22 & 0 & 0.520 & 0.171 & 0.184 & 0.856 \\
\hline 8635 & 40.495536 & -83.899880 & TPL & 303.7 & 2018.9 & EUT & 209 & 32.0 & 12.9 & 1 & 21 & 0 & 0.343 & 0.138 & 0.072 & 0.614 \\
\hline 8765 & 37.595562 & -112.254669 & WMT & 2389.9 & 70.2 & EUT & 222 & 39.8 & 12.0 & 1 & 25 & 0 & 0.371 & 0.112 & 0.151 & 0.592 \\
\hline 8766 & 40.863781 & -109.811815 & WMT & 2528.1 & 18.1 & EUT & 222 & 39.8 & 12.0 & 1 & 13 & 0 & 0.673 & 0.204 & 0.274 & 1.072 \\
\hline 8777 & 39.360351 & -111.963708 & XER & 1521.4 & 3220.7 & EUT & 213 & 31.0 & 11.6 & 1 & 3 & 0 & 0.903 & 0.337 & 0.242 & 1.565 \\
\hline 1000019 & 43.460190 & -116.141301 & XER & 973.1 & 33.4 & EUT & 213 & 31.0 & 11.6 & 1 & 25 & 0 & 0.193 & 0.072 & 0.052 & 0.334 \\
\hline 1000025 & 43.198407 & -114.599726 & XER & 1678.7 & 44.6 & EUT & 213 & 31.0 & 11.6 & 1 & 27 & 0 & 0.129 & 0.048 & 0.034 & 0.223 \\
\hline 1000029 & 42.677045 & -113.407296 & XER & 1278.7 & 3395.5 & EUT & 213 & 31.0 & 11.6 & 1 & 12 & 0 & 0.613 & 0.229 & 0.164 & 1.061 \\
\hline 1000030 & 42.206372 & -114.878852 & XER & 1593.0 & 393.0 & EUT & 213 & 31.0 & 11.6 & 1 & 20 & 0 & 0.354 & 0.132 & 0.095 & 0.614 \\
\hline 1000068 & 46.206071 & -116.834367 & XER & 1034.1 & 38.1 & EUT & 213 & 31.0 & 11.6 & 1 & 22 & 0 & 0.290 & 0.108 & 0.078 & 0.502 \\
\hline 1000073 & 35.582330 & -101.717139 & SPL & 894.9 & 6559.4 & EUT & 176 & 26.1 & 13.1 & 1 & 9 & 0 & 0.656 & 0.329 & 0.011 & 1.301 \\
\hline 1000084 & 41.037407 & -100.775775 & SPL & 916.0 & 641.0 & EUT & 176 & 26.1 & 13.1 & 1 & 15 & 0 & 0.426 & 0.214 & 0.007 & 0.846 \\
\hline 1000086 & 41.321987 & -98.900675 & SPL & 657.7 & 1117.9 & EUT & 176 & 26.1 & 13.1 & 1 & 15 & 0 & 0.426 & 0.214 & 0.007 & 0.846 \\
\hline 1000122 & 42.264258 & -116.310496 & XER & 1690.0 & 35.5 & EUT & 213 & 31.0 & 11.6 & 1 & 25 & 0 & 0.193 & 0.072 & 0.052 & 0.334 \\
\hline 1000126 & 42.531475 & -116.364513 & XER & 1773.6 & 29.4 & EUT & 213 & 31.0 & 11.6 & 1 & 23 & 0 & 0.258 & 0.096 & 0.069 & 0.446 \\
\hline 1000137 & 42.187306 & -113.924080 & XER & 1444.7 & 407.4 & OLI & 213 & 31.0 & 11.6 & 1 & 11 & 0 & 0.645 & 0.241 & 0.173 & 1.117 \\
\hline 1000223 & 43.537123 & -90.959353 & UMW & 277.4 & 14.8 & EUT & 167 & 39.3 & 12.7 & 1 & 25 & 0 & 0.364 & 0.118 & 0.133 & 0.595 \\
\hline
\end{tabular}




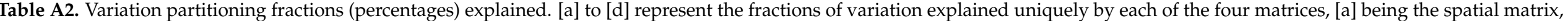

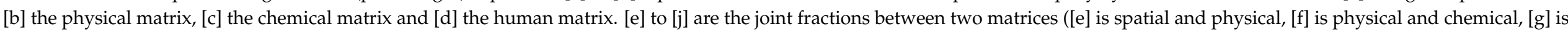

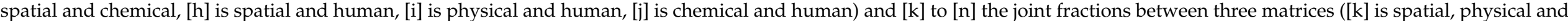
human, [1] is spatial, physical and chemical, [m] is physical, chemical and human, and [n] is spatial, chemical and human). Finally, [o] is the joint fraction between all four matrices.

\begin{tabular}{|c|c|c|c|c|c|c|c|c|c|c|c|c|c|c|c|c|}
\hline$\%$ & [a] & {$[b]$} & [c] & [d] & [e] & [f] & [g] & [h] & [i] & [j] & [k] & [1] & [m] & [n] & [o] & Value \\
\hline 51 & 0.2 & 14.8 & 5.2 & 0.0 & 9.4 & 0.6 & 0.9 & -0.2 & 3.8 & 0.4 & 4.8 & 5.9 & 1.3 & -0.1 & 3.9 & 51.0 \\
\hline 45 & 0.2 & 14.8 & & & 9.4 & 0.6 & 0.9 & -0.2 & 3.8 & & 4.8 & 5.9 & 1.3 & -0.1 & 3.9 & 45.4 \\
\hline 25 & 0.2 & & & & 9.4 & & 0.9 & -0.2 & & & 4.8 & 5.9 & & -0.1 & 3.9 & 24.9 \\
\hline 24 & & & & & 9.4 & & & & & & 4.8 & 5.9 & & & 3.9 & 24.1 \\
\hline 11 & & & & & & & 0.9 & & & & & 5.9 & & -0.1 & 3.9 & 10.7 \\
\hline 8 & & & & & & & & -0.2 & & & 4.8 & & & -0.1 & 3.9 & 8.4 \\
\hline 45 & & 14.8 & & & 9.4 & 0.6 & & & 3.8 & & 4.8 & 5.9 & 1.3 & & 3.9 & 44.6 \\
\hline 15 & & 14.8 & & & & & & & & & & & & & & 14.8 \\
\hline 18 & & & 5.2 & & & 0.6 & 0.9 & & & 0.4 & & 5.9 & 1.3 & -0.1 & 3.9 & 18.1 \\
\hline 14 & & & & 0.0 & & & & -0.2 & 3.8 & 0.4 & 4.8 & & 1.3 & -0.1 & 3.9 & 14.0 \\
\hline
\end{tabular}



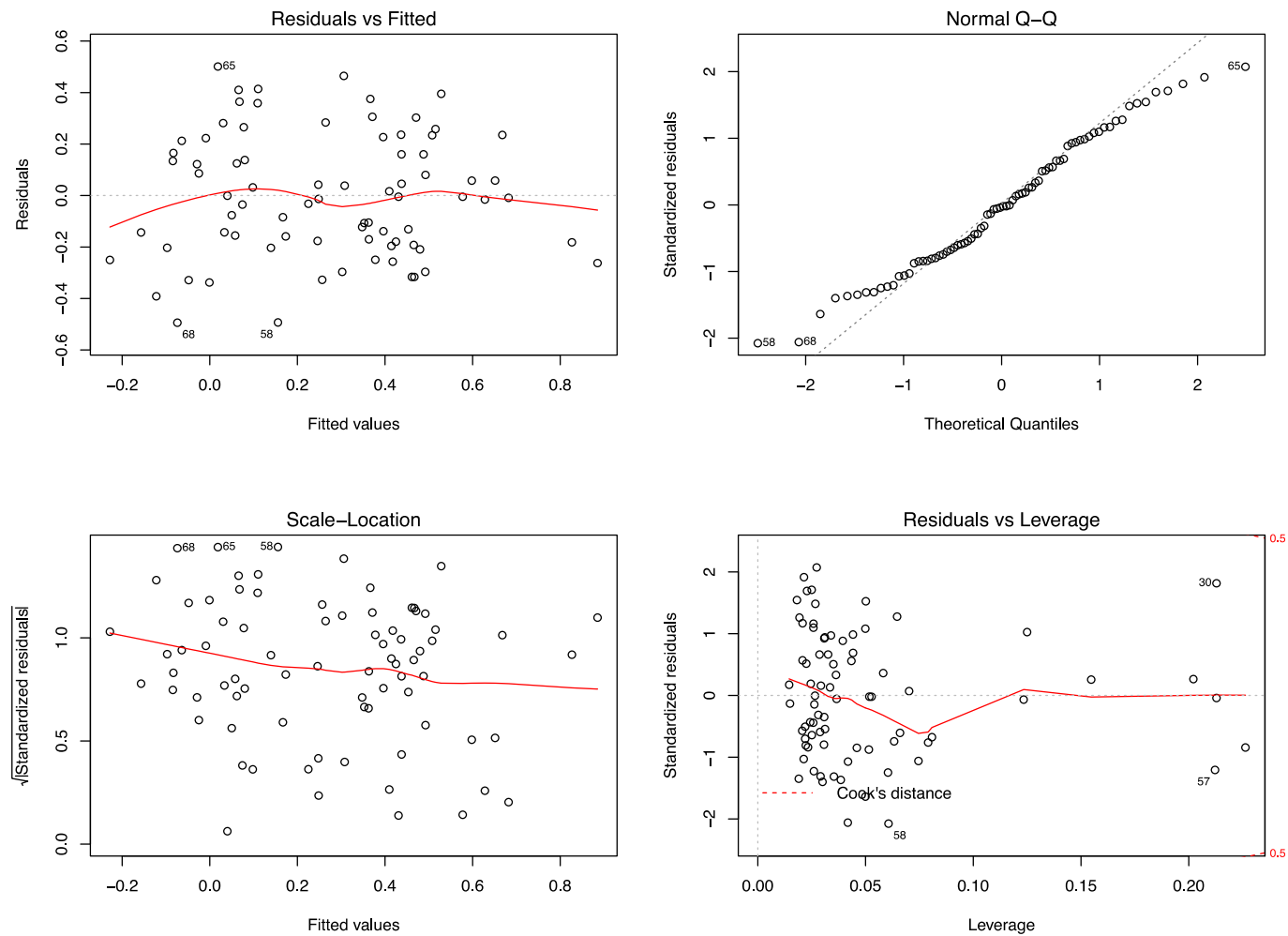

Figure A1. Graphical series used to validate three of the four assumptions of the explanatory linear model multiple regression, that is the normality of the residuals (Normal Q-Q plot), residuals mean of 0 (Residuals vs. Fitted plot), and the homoscedasticity of the residuals (Residuals vs. Fitted plot and Scale-Location plot). In addition to the assumptions, we can also check for leverage points in the dataset using the Residuals vs. Leverage plot.

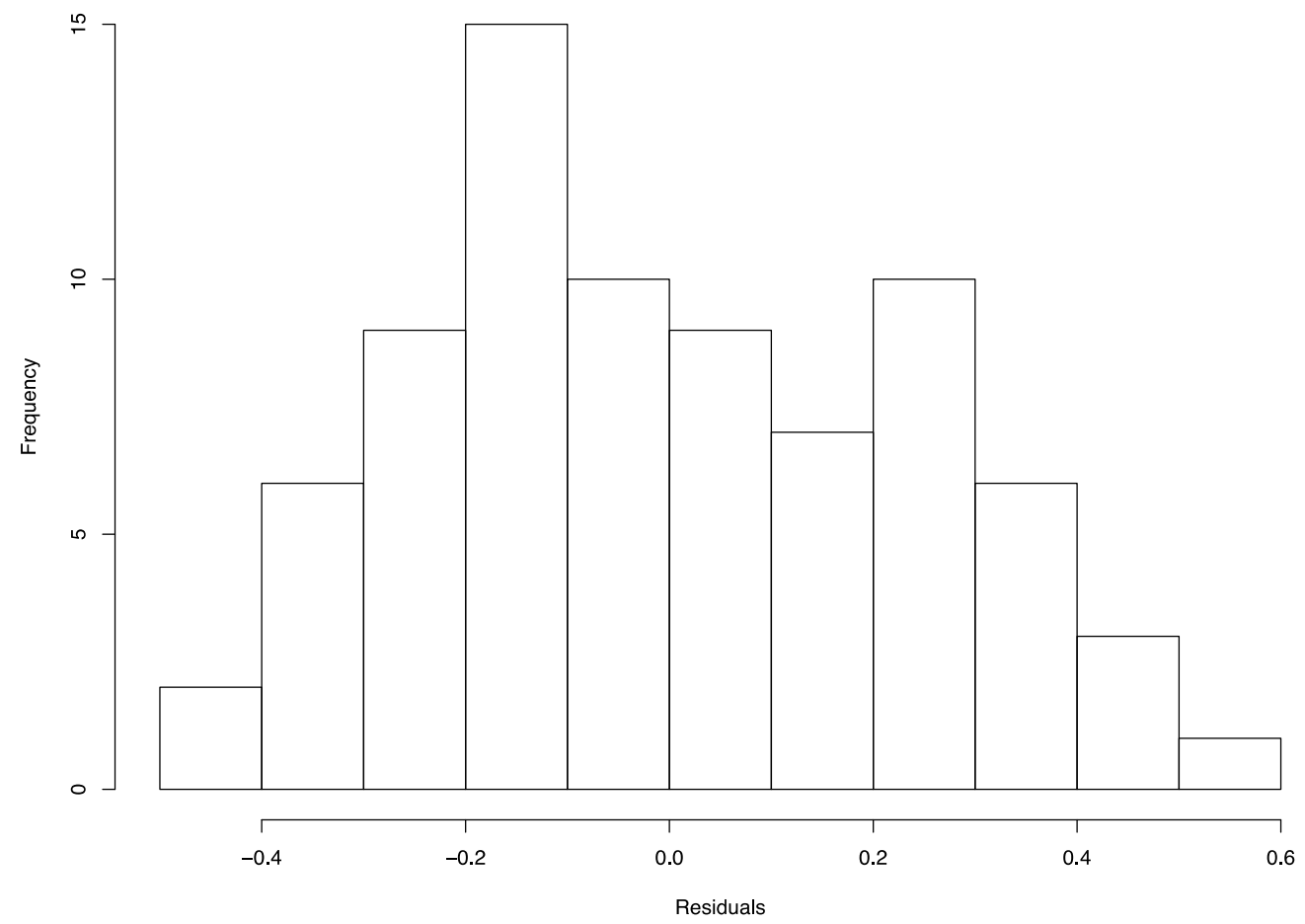

Figure A2. Frequency histogram of the residuals to double check the normality of the model's residuals (D), further confirmed by a Shapiro normality test ( $p$-value $=0.216$, thus considered normal). 


\section{References}

1. Richter, B.D.; Mathews, R.; Harrison, D.L.; Wigington, R. Ecologically sustainable water management: Managing river flows for ecological integrity. Ecol. Appl. 2003, 13, 206-224. [CrossRef]

2. Lehner, B.; Liermann, C.R.; Revenga, C.; Vörösmarty, C.J.; Fekete, B.M.; Crouzet, P.; Döll, P.; Endejan, M.; Frenken, K.; Magome, J.; et al. High-resolution mapping of the world's reservoirs and dams for sustainable river-flow management. Front. Ecol. Environ. 2011, 9, 494-502. [CrossRef]

3. Chen, J.; Shi, H.; Sivakumar, B.; Peart, M.R. Population, water, food, energy and dams. Renew. Sustain. Energy Rev. 2016, 56, 18-28. [CrossRef]

4. Rosenberg, D.M.; McCully, P.; Pringle, C.M. Global-scale environmental effects of hydrological alterations: Introduction. Bioscience 2000, 50, 746-751. [CrossRef]

5. Vörösmarty, C.J. Chapter 7: Fresh Water. In Millennium Ecosystem Assessment, Volume 1: Conditions and Trends Working Group Report; Island Press: Washington, DC, USA, 2005.

6. Abell, R.; Thieme, M.L.; Revenga, C.; Bryer, M.; Kottelat, M.; Bogutskaya, N.; Coad, B.; Mandrak, N.; Balderas, S.C.; Bussing, W.; et al. Freshwater ecoregions of the world: A new map of biogeographic units for freshwater biodiversity conservation. Bioscience 2008, 58, 403-414. [CrossRef]

7. Renöfält, B.M.; Jansson, R.; Nilsson, C. Effects of hydropower generation and opportunities for environmental flow management in Swedish riverine ecosystems. Freshw. Biol. 2010, 55, 49-67. [CrossRef]

8. Gracey, E.O.; Verones, F. Impacts from hydropower production on biodiversity in an LCA framework-review and recommendations. Int. J. Life Cycle Assess. 2016, 21, 412-428. [CrossRef]

9. Agostinho, A.; Pelicice, F.; Gomes, L. Dams and the fish fauna of the Neotropical region: Impacts and management related to diversity and fisheries. Braz. J. Biol. 2008, 68, 1119-1132. [CrossRef] [PubMed]

10. Ryder, R.A. The morphoedaphic index-use, abuse, and fundamental concepts. Trans. Am. Fish. Soc. 1982, 111, 154-164. [CrossRef]

11. Youngs, W.D.; Heimbuch, D.G. Another consideration of the morphoedaphic index. Trans. Am. Fish. Soc. 1982, 111, 151-153. [CrossRef]

12. Jackson, D.A.; Harvey, H.H.; Somers, K.M. Ratios in aquatic sciences: Statistical shortcomings with mean depth and the morphoedaphic index. Can. J. Fish. Aquat. Sci. 1990, 47, 1788-1795. [CrossRef]

13. Rempel, R.S.; Colby, P.J. A statistically valid model of the morphoedaphic index. Can. J. Fish. Aquat. Sci. 1991, 48, 1937-1943. [CrossRef]

14. Poff, N.L.; Allan, J.D.; Bain, M.B.; Karr, J.R.; Prestegaard, K.L.; Richter, B.D.; Sparks, R.E.; Stromberg, J.C. The natural flow regime. Bioscience 1997, 47, 769-784. [CrossRef]

15. Bunn, S.E.; Arthington, A.H. Basic principles and ecological consequences of altered flow regimes for aquatic biodiversity. Environ. Manag. 2002, 30, 492-507. [CrossRef] [PubMed]

16. Dudgeon, D.; Arthington, A.H.; Gessner, M.O.; Kawabata, Z.-I.; Knowler, D.J.; Lévêque, C.; Naiman, R.J.; Prieur-Richard, A.-H.; Soto, D.; Stiassny, M.L.J.; et al. Freshwater biodiversity: Importance, threats, status and conservation challenges. Biol. Rev. 2006, 81, 163-182. [CrossRef]

17. Kraft, K.J. Effect of Increased Winter Drawdown on Benthic Macroinvertebrates in Namakan Reservoir, Voyeurs National Park; Michigan Techonological University: Houghton, MI, USA, 1988; p. 86.

18. Englund, G.; Malmqvist, B. Effects of flow regulation, habitat area and isolation on the macroinvertebrate fauna of rapids in North Swedish rivers. Regul. Rivers Res. Manag. 1996, 12, 433-445. [CrossRef]

19. Malmqvist, B.; Englund, G. Effects of hydropower-induced flow perturbations on mayfly (Ephemeroptera) richness and abundance in north Swedish river rapids. Hydrobiology 1996, 341, 145-158. [CrossRef]

20. Valdovinos, C.; Moya, C.; Olmos, V.; Parra, O.; Karrasch, B.; Buettner, O. The importance of water-level fluctuation for the conservation of shallow water benthic macroinvertebrates: An example in the Andean zone of Chile. Biodivers. Conserv. 2007, 16, 3095-3109. [CrossRef]

21. Aroviita, J.; Hämäläinen, H. The impact of water-level regulation on littoral macroinvertebrate assemblages in boreal lakes. Hydrobiol. 2008, 613, 45-56. [CrossRef]

22. White, M.S.; Xenopoulos, M.A.; Metcalfe, R.A.; Somers, K.M. Water level thresholds of benthic macroinvertebrate richness, structure, and function of boreal lake stony littoral habitats. Can. J. Fish. Aquat. Sci. 2011, 68, 1695-1704. [CrossRef]

23. Behrend, R.D.L.; Takeda, A.; Gomes, L.; Fernandes, S.E.P. Using oligochaeta assemblages as an indicator of environmental changes. Braz. J. Biol. 2012, 72, 873-884. [CrossRef]

24. Jackson, H.M.; Gibbins, C.N.; Soulsby, C. Role of discharge and temperature variation in determining invertebrate community structure in a regulated river. River Res. Appl. 2007, 23, 651-669. [CrossRef]

25. Kullasoot, S.; Intrarasattayapong, P.; Phalaraksh, C. Use of benthic macroinvertebrates as bioindicators of anthropogenic impacts on water quality of Mae Klong River, Western Thailand. Chiang Mai J. Sci. 2017, 44, 1356-1366.

26. Takao, A.; Kawaguchi, Y.; Minagawa, T.; Kayaba, Y.; Morimoto, Y. The relationships between benthic macroinvertebrates and biotic and abiotic environmental characteristics downstream of the Yahagi Dam, Central Japan, and the State Change Caused by inflow from a Tributary. River Res. Appl. 2008, 24, 580-597. [CrossRef] 
27. Głowacki, Ł.; Grzybkowska, M.; Dukowska, M.; Penczak, T. Effects of damming a large lowland river on chironomids and fish assessed with the (multiplicative partitioning of) true/Hill biodiversity measure. River Res. Appl. 2010, 27, 612-629. [CrossRef]

28. Floss, E.C.S.; Secretti, E.; Kotzian, C.B.; Spies, M.R.; Pires, M.M. Spatial and temporal distribution of non-biting midge larvae assemblages in streams in a mountainous region in Southern Brazil. J. Insect Sci. 2013, 13, 1-27. [CrossRef]

29. Smokorowski, K.E.; Metcalfe, R.A.; Finucan, S.D.; Jones, N.; Marty, J.; Power, M.; Pyrce, R.S.; Steele, R. Ecosystem level assessment of environmentally based flow restrictions for maintaining ecosystem integrity: A comparison of a modified peaking versus unaltered river. Ecohydrology 2010, 4, 791-806. [CrossRef]

30. Marchetti, M.P.; Esteban, E.; Smith, A.N.; Pickard, D.; Richards, A.B.; Slusark, J. Measuring the ecological impact of long-term flow disturbance on the macroinvertebrate community in a large Mediterranean climate river. J. Freshw. Ecol. 2011, 26, 1-22. [CrossRef]

31. ISO. ISO 14040: Environmental Management_Life Cycle Assessment; BSI: London, UK, 2006.

32. Hellweg, S.; Milà I Canals, L. Emerging approaches, challenges and opportunities in life cycle assessment. Science 2014, 344, 1109-1113. [CrossRef] [PubMed]

33. Curran, M.; De Baan, L.; De Schryver, A.M.; Van Zelm, R.; Hellweg, S.; Koellner, T.; Sonnemann, G.; Huijbregts, M.A.J. Toward meaningful end points of biodiversity in life cycle assessment. Environ. Sci. Technol. 2011, 45, 70-79. [CrossRef] [PubMed]

34. Verones, F.; Bare, J.; Bulle, C.; Frischknecht, R.; Hauschild, M.; Hellweg, S.; Henderson, A.; Jolliet, O.; Laurent, A.; Liao, X.; et al. LCIA framework and cross-cutting issues guidance within the UNEP-SETAC Life Cycle Initiative. J. Clean. Prod. 2017, 161, 957-967. [CrossRef]

35. Turgeon, K.; Trottier, G.; Turpin, C.; Bulle, C.; Margni, M. Empirical characterization factors to be used in LCA and assessing the effects of hydropower on fish richness. Ecol. Indic. 2021, 121, 107047. [CrossRef]

36. Dorber, M.; Mattson, K.R.; Sandlund, O.T.; May, R.; Verones, F. Quantifying net water consumption of Norwegian hydropower reservoirs and related aquatic biodiversity impacts in Life Cycle Assessment. Environ. Impact Assess. Rev. 2019, 76, 36-46. [CrossRef]

37. Xenopoulos, M.A.; Lodge, D.M. Going with the flow: Using species-discharge relationships to forecast losses in fish biodiversity. Ecology 2006, 87, 1907-1914. [CrossRef]

38. Pickett, S.T.A. Space-for-time substitution as an alternative to long-term studies. In Long-Term Studies in Ecology; Likens, G.E., Ed.; Springer: New York, NY, USA, 1989; pp. 110-135; ISBN 978-1-4615-7360-9.

39. Rosenbaum, R.K.; Bachmann, T.M.; Gold, L.S.; Huijbregts, M.A.J.; Jolliet, O.; Juraske, R.; Koehler, A.; Larsen, H.F.; MacLeod, M.; Margni, M.; et al. USEtox - the UNEP-SETAC toxicity model: Recommended characterisation factors for human toxicity and freshwater ecotoxicity in life cycle impact assessment. Int. J. Life Cycle Assess. 2008, 13, 532-546. [CrossRef]

40. De Baan, L.; Mutel, C.L.; Curran, M.; Hellweg, S.; Koellner, T. Land use in life cycle assessment: Global characterization factors based on regional and global potential species extinction. Environ. Sci. Technol. 2013, 47, 9281-9290. [CrossRef]

41. Jolliet, O.; Margni, M.; Charles, R.; Humbert, S.; Payet, J.; Rebitzer, G.; Rosenbaum, R. IMPACT 2002+: A new life cycle impact assessment methodology. Int. J. Life Cycle Assess. 2003, 8, 324-330. [CrossRef]

42. Goedkoop, M.; Heijungs, R.; Huijbregts, M.; De Schryver, A.; Struijs, J.; van Zelm, R. ReCiPe 2008—Life Cycle Impact Assessment Which Comprises Harmonized Category Indicators at the Midpoint and Endpoint Level. 2009. Available online: https://www. researchgate.net/profile/Mark_Goedkoop/publication/230770853_Recipe_2008/links/09e4150dc068ff22e9000000.pdf (accessed on 2 March 2021).

43. Chaudhary, A.; Verones, F.; De Baan, L.; Hellweg, S. Quantifying Land Use Impacts on Biodiversity: Combining Species-Area Models and Vulnerability Indicators. Environ. Sci. Technol. 2015, 49, 9987-9995. [CrossRef]

44. Lindeijer, E.; Müller-Wenk, R.; Steen, B. Impact assessment of resources and land use. In Life Cycle Impact Assessment: Striving towards Best Practice; SETAC: Pensacola, FL, USA, 2002; pp. 11-64.

45. Milà i Canals, L.M.I.; Bauer, C.; Depestele, J.; Dubreuil, A.; Freiermuth Knuchel, R.; Gaillard, G.; Michelsen, O.; Müller-Wenk, R.; Rydgren, B. Key elements in a framework for land use impact assessment within LCA (11 pp). Int. J. Life Cycle Assess. 2007, 12, 5-15. [CrossRef]

46. USEPA. National Lakes Assessment. Available online: https://www.epa.gov/national-aquatic-resource-surveys/nla (accessed on 16 January 2019).

47. USEPA. National Lake Assessment 2012: Technical Report; U.S. Environmental Protection Agency: Washington, DC, USA, 2017.

48. USEPA. National Rivers and Streams Assessment. Available online: https:/ / www.epa.gov/national-aquatic-resource-surveys / nrsa (accessed on 16 January 2019).

49. Banet, A.I.; Trexler, J.C. Space-for-time substitution works in everglades ecological forecasting models. PLoS ONE 2013,8 , e81025. [CrossRef]

50. USEPA. 2012 National Lakes Assessment. Field Operations Manual; U.S. Environmental Protection Agency: Washington, DC, USA, $2011 ;$ p. 234.

51. USEPA. National Rivers and Streams Assessment: Field Operations Manual; U.S. Environmental Protection Agency: Washington, DC, USA, 2007.

52. Omernik, J.M. Ecoregions of the conterminous United States. Ann. Assoc. Am. Geogr. 1987, 77, 118-125. [CrossRef] 
53. Herlihy, A.T.; Paulsen, S.G.; Van Sickle, J.; Stoddard, J.L.; Hawkins, C.P.; Yuan, L.L. Striving for consistency in a national assessment: The challenges of applying a reference-condition approach at a continental scale. J. N. Am. Benthol. Soc. 2008, 27, 860-877. [CrossRef]

54. USEPA. Ecoregions Used in the National Aquatic Resource Surveys. Available online: https://www.epa.gov/national-aquaticresource-surveys / ecoregions-used-national-aquatic-resource-surveys (accessed on 16 January 2019).

55. Patouillard, L.; Bulle, C.; Margni, M. Ready-to-use and advanced methodologies to prioritise the regionalisation effort in LCA. Matériaux Tech. 2016, 104, 105. [CrossRef]

56. Yang, Y. Two sides of the same coin: Consequential life cycle assessment based on the attributional framework. J. Clean. Prod. 2016, 127, 274-281. [CrossRef]

57. R Core Team. R: A Language and Environment for Statistical Computing; R Foundation for Statistical Computing: Vienna, Austria, 2017.

58. Okumura, Y. Rpsychi: Statistics for Psychiatric Research; 2012.

59. Legendre, P. Studying beta diversity: Ecological variation partitioning by multiple regression and canonical analysis. J. Plant Ecol. 2007, 1, 3-8. [CrossRef]

60. Oksanen, J.; Blanchet, F.G.; Friendly, M.; Kindt, R.; Legendre, P.; McGlinn, D.; O'Hara, R.B.; Simpson, G.L.; Solymos, P.; Stevens, M.H.H.; et al. Vegan: Community Ecology Package; 2019.

61. Burnham, K.P.; Anderson, D.R. Model Selection and Multimodel Inference; Springer: New York, NY, USA, 2004; ISBN 978-0-38795364-9.

62. Schwarz, G. Estimating the dimension of a model. Ann. Stat. 1978, 6, 461-464. [CrossRef]

63. García-Vega, D.; Newbold, T. Assessing the effects of land use on biodiversity in the world's drylands and Mediterranean environments. Biodivers. Conserv. 2019, 29, 393-408. [CrossRef]

64. Harrison, S.; Noss, R. Endemism hotspots are linked to stable climatic refugia. Ann. Bot. 2017, 119, 207-214. [CrossRef] [PubMed]

65. Mykrä, H.; Heino, J. Decreased habitat specialization in macroinvertebrate assemblages in anthropogenically disturbed streams. Ecol. Complex. 2017, 31, 181-188. [CrossRef]

66. Viterbi, R.; Cerrato, C.; Bassano, B.; Bionda, R.; Von Hardenberg, A.; Provenzale, A.; Bogliani, G. Patterns of biodiversity in the northwestern Italian Alps: A multi-taxa approach. Community Ecol. 2013, 14, 18-30. [CrossRef]

67. Wetzel, R.G. Limnology: Lake and River Ecosystems; Academic Press: San Diego, CA, USA, 2001; ISBN 978-0-12-744760-5.

68. Dodson, S.I.; Arnott, S.E.; Cottingham, K.L. The relationship in lake communities between primary productivity and species richness. Ecology 2000, 81, 2662-2679. [CrossRef]

69. Heino, J.; Tolonen, K.T. Ecological drivers of multiple facets of beta diversity in a lentic macroinvertebrate metacommunity. Limnol. Oceanogr. 2017, 62, 2431-2444. [CrossRef]

70. Jackson, D.A.; Peres-Neto, P.R.; Olden, J.D. What controls who is where in freshwater fish communities-the roles of biotic, abiotic, and spatial factors. Can. J. Fish. Aquat. Sci. 2001, 58, 157-170. [CrossRef]

71. Tonn, W.M.; Magnuson, J.J. Patterns in the species composition and richness of fish assemblages in Northern Wisconsin Lakes. Ecology 1982, 63, 1149-1166. [CrossRef]

72. Heino, J. Lentic macroinvertebrate assemblage structure along gradients in spatial heterogeneity, habitat size and water chemistry. Hydrobiologia 2000, 418, 229-242. [CrossRef]

73. Connor, E.F.; McCoy, E.D. The statistics and biology of the species-area relationship. Am. Nat. 1979, 113, 791-833. [CrossRef]

74. MacArthur, R.H.; Wilson, E.O. The Theory of Island Biogeography; Princeton University Press: Princeton, NJ, USA, 2001; ISBN 978-0-691-08836-5.

75. Verones, F.; Hanafiah, M.M.; Pfister, S.; Huijbregts, M.A.J.; Pelletier, G.J.; Koehler, A. Characterization factors for thermal pollution in freshwater aquatic environments. Environ. Sci. Technol. 2010, 44, 9364-9369. [CrossRef]

76. Williams, C.B. Patterns in the Balance of Nature and Related Problems in Quantitative Ecology; Academic Press: Cambridge, MA, USA, 1964.

77. Horwitz, R.J. Temporal variability patterns and the distributional patterns of stream fishes. Ecol. Monogr. 1978, 48, 307-321. [CrossRef]

78. Moyle, P.B.; Li, H.W. Community ecology and predator-prey relations in warmwater streams. In Predator-Prey Systems in Fisheries Management; Clepper, H., Ed.; Sport Fishing Institute: Washington, DC, USA, 1979; pp. 171-180.

79. Eadie, J.M.; Hurly, T.A.; Montgomerie, R.D.; Teather, K.L. Lakes and rivers as islands: Species-area relationships in the fish faunas of Ontario. Environ. Biol. Fishes 1986, 15, 81-89. [CrossRef]

80. Gorman, O.T.; Karr, J.R. Habitat structure and stream fish communities. Ecology 1978, 59, 507-515. [CrossRef]

81. Matthews, W.J. Small fish community structure in Ozark streams: Structured assembly patterns or random abundance of species? Am. Midl. Nat. 1982, 107, 42. [CrossRef]

82. Walker, K.F.; Thoms, M.C.; Sheldon, F. Effects of weirs on the littoral environment of the River Murray, South Australia. In River Conservation and Management; Boon, P.J., Calow, P., Petts, G.E., Eds.; John Wiley \& Sons: Chichester, UK, $1992 ;$ pp. $271-292$.

83. Bulle, C.; Margni, M.; Patouillard, L.; Boulay, A.-M.; Bourgault, G.; De Bruille, V.; Cao, V.; Hauschild, M.; Henderson, A.; Humbert, S.; et al. IMPACT World+: A globally regionalized life cycle impact assessment method. Int. J. Life Cycle Assess. 2019, 24, 1653-1674. [CrossRef] 